Prepared in cooperation with the U.S. Fish and Wildlife Service

\title{
A Comprehensive List and Photographic Collection of the Vascular Flora of Caddo Lake National Wildlife Refuge, Texas, March 2011-March 2012
}

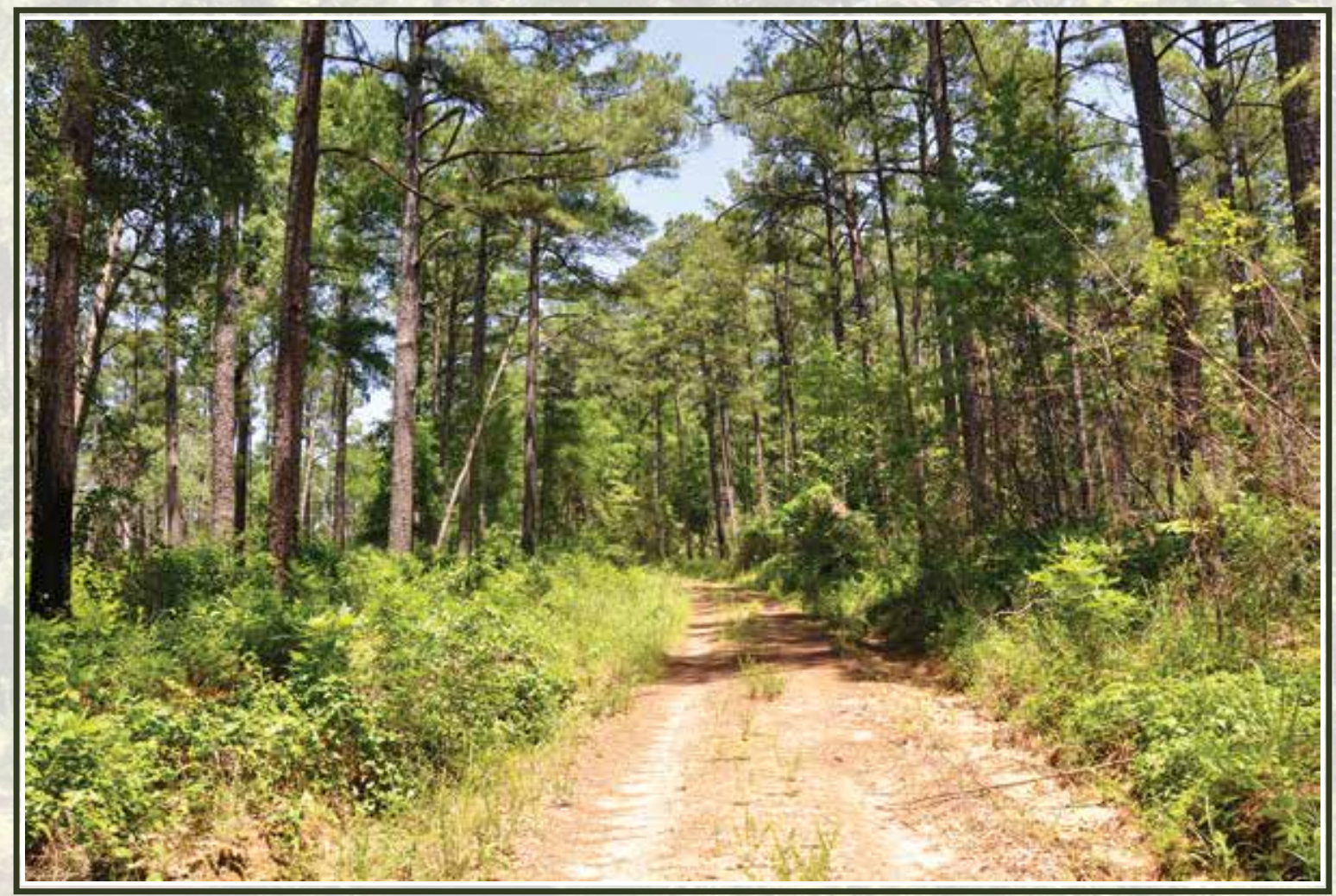

Data Series 854 
Cover, Caddo Lake National Wildlife Refuge, Texas, August 2011. 


\section{A Comprehensive List and Photographic Collection of the Vascular Flora of Caddo Lake National Wildlife Refuge, Texas, March 2011-March 2012}

By Larry Allain

Prepared in cooperation with the U.S. Fish and Wildlife Service

Data Series 854 


\section{U.S. Department of the Interior \\ SALLY JEWELL, Secretary}

\section{U.S. Geological Survey \\ Suzette M. Kimball, Acting Director}

\section{U.S. Geological Survey, Reston, Virginia: 2014}

For more information on the USGS — the Federal source for science about the Earth, its natural and living resources, natural hazards, and the environment, visit http://www.usgs.gov or call 1-888-ASK-USGS.

For an overview of USGS information products, including maps, imagery, and publications, visit http://www.usgs.gov/pubprod

To order this and other USGS information products, visit http://store.usgs.gov

Any use of trade, firm, or product names is for descriptive purposes only and does not imply endorsement by the U.S. Government.

Although this information product, for the most part, is in the public domain, it also may contain copyrighted materials as noted in the text. Permission to reproduce copyrighted items must be secured from the copyright owner.

Suggested citation:

Allain, Larry, 2014, A comprehensive list and photographic collection of the vascular flora of Caddo Lake National Wildlife Refuge, Texas, March 2011-March 2012: U.S. Geological Survey Data Series 854, 41 p., http://dx.doi. org/10.3133/ds854.

ISSN 2327-638X (online) 


\section{Contents}

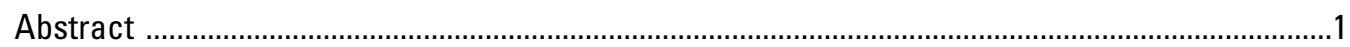

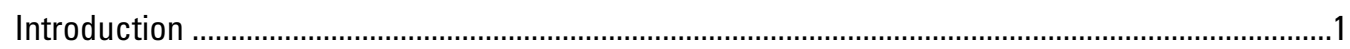

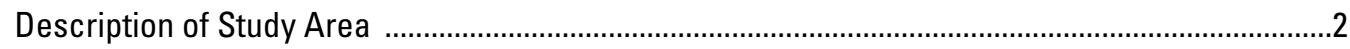

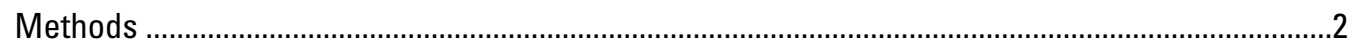

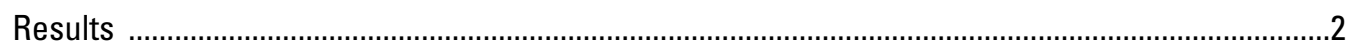

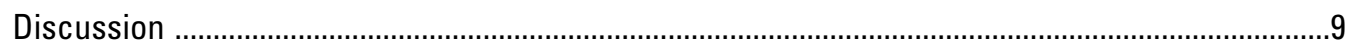

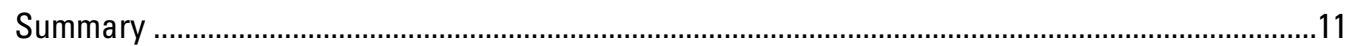

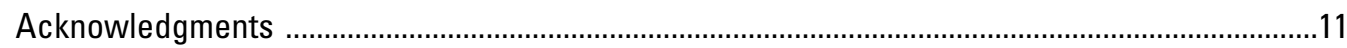

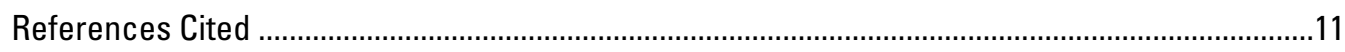

Photograph Collection (available at http://pubs.usgs.gov/ds/854/)

\section{Figures}

1. Map showing location of Caddo Lake National Wildlife Refuge, Texas ............................3

2. Photograph showing chambered pith of black walnut (Juglans nigra), an example of diagnostic plant characters photographed during this project at Caddo Lake National Wildlife Refuge, Texas

3. Photographs showing the differences in leaf form of two varieties of Taxodium distichum occurring on Caddo Lake National Wildlife Refuge, Texas

4. Photograph showing pine-hardwood forest predominant on slopes and other well-drained sites in Caddo Lake National Wildlife Refuge, Texas

5. Photograph showing bottomland hardwoods dominated by baldcypress (Taxodium distichum var. distichum) along drainages and in frequently flooded parts of Caddo Lake National Wildlife Refuge, Texas

6. Photograph showing Chinese tallow tree (Triadica sebifera), an invasive nonnative species that is currently controlled by refuge management at Caddo Lake National Wildlife Refuge, Texas

7. Photograph showing staff of Caddo Lake National Wildlife Refuge, Texas, using herbicide to treat small Chinese tallow trees (Triadica sebifera) before these nonnative, highly invasive trees can bear seeds and colonize additional area

8. Photograph showing an invasive understory shrub, sacred bamboo (Nandina domestica), that was collected on a small outholding of Caddo Lake National Wildlife Refuge, Texas, north of Texas Farm to Market Road 2198 (FM 2198)

9. Photograph showing giant salvinia (Salvinia molesta), considered one of the world's worst aquatic pests

10. Photograph showing a three-toed box turtle (Terrapene carolina triunguis), so named because of the number of toes on the back feet, at Caddo Lake National Wildlife Refuge, Texas

11. Photograph showing American lady butterfly (Vanessa virginiensis) nectering on the flowers of groovestem Indian plantain (Arnoglossum plantagineum) on a roadside along the Auto Route in Caddo Lake National Wildlife Refuge, Texas 


\section{Tables}

1. Comprehensive list of vascular plants identified at Caddo Lake National Wildlife Refuge, Texas, March 2011-March 2012 .......................................................................12

2. List of nonnative plant species occurring at Caddo Lake National Wildlife Refuge, Texas, March 2011-March 2012

3. List of vascular plant species found at Caddo Lake National Wildlife Refuge, Texas, March 2011-March 2012, with food value for wildlife

\section{Conversion Factors}

Inch/Pound to SI

\begin{tabular}{|c|c|c|}
\hline Multiply & By & To obtain \\
\hline \multicolumn{3}{|c|}{ Length } \\
\hline mile (mi) & 1.609 & kilometer $(\mathrm{km})$ \\
\hline
\end{tabular}

SI to Inch/Pound

\begin{tabular}{lccc}
\hline Multiply & By & To obtain \\
\hline & Area & \\
\hline hectare (ha) & 2.471 & acre \\
\hline
\end{tabular}




\title{
A Comprehensive List and Photographic Collection of the Vascular Flora of Caddo Lake National Wildlife Refuge, Texas, March 2011-March 2012
}

\author{
By Larry Allain
}

\section{Abstract}

A floristics inventory was conducted to identify and photograph the vascular plants occurring at Caddo Lake National Wildlife Refuge (NWR), Texas, from March 2011 to March 2012 by the U.S. Geological Survey in cooperation with the U.S. Fish and Wildlife Service. This research resulted in the identification of 511 taxa of vascular plants representing 111 families and 317 genera. Despite the degree of development of the refuge at the time it was transferred to the U.S. Fish and Wildlife Service, plant diversity was high. Of the 511 species identified in this study, 346 species are new records for Harrison County, and 3 species are new discoveries for Texas. Caddo Lake NWR is primarily forested with 55 tree species and 35 shrub species identified in this study. Of the species identified, 289 are associated with wetlands having a wetland classification of facultative or wetter, possibly reflecting the proximity of Caddo Lake to the refuge and the three streams that intersect the refuge. Sixty-two of the species found on the refuge are introduced. Chinese tallow tree (Triadica sebifera) is one of the more common invasive tree species on the refuge and is actively controlled by refuge staff. Chinese privet (Ligustrum sinense), sacred bamboo (Nandina domestica), and King's Ranch bluestem (Bothriochloa ischaemum var. songarica) are present on the refuge and have the potential to become invasive. More than 10,000 photographs were taken of the plants found on the refuge in an effort to document general appearance and capture diagnostic characters of each plant species. Photographs were also taken of many of the animals and landscapes encountered during the project. Select images of each of the plants and animals are included in the collection of more than 1,600 photographs (all photographs by Larry Allain).

\section{Introduction}

The National Wildlife Refuge System was established to manage lands and waters in the United States for conservation and restoration of fish, wildlife, and plant resources. There are 560 national wildlife refuges in all, covering 61 million hectares nationwide (U.S. Fish and Wildlife Service, 2013). Individual refuges are unique and established for a variety of purposes including the protection of endangered species; the preservation of habitat for plants and animals threatened by development or overutilization; the creation of habitat connections and corridors within landscapes for migratory animals; use as a recreational destination for hunting, fishing, wildlife observation, and photography; facilitating environmental education and interpretation; and restoring lands and waters that have been damaged by past use. Most national wildlife refuges have become general refuges for every kind of wildlife that can appropriately be sheltered in that environment. Maintaining and improving habitat quality require that the biological integrity, diversity, and environmental health of refuge resources be conserved.

To achieve these goals, each refuge is required by the National Wildlife Refuge System Administration Act of 1997 to develop a 15-year comprehensive conservation plan. Implementation of these plans requires the use of adaptive management that relies on surveys, inventory and monitoring of resources, management practices, and experiments. The information gained is then used to alter and refine management practices. A critical component of this process includes the development of a comprehensive list of the vascular plant species that occur on a refuge. Management goals are affected when endangered species are identified. Managing and restoring habitat require knowledge of existing plant communities and the species they contain. Monitoring invasive plant populations is necessary for their control or eradication, and controlling new invasive plant problems is most efficient when they are detected early in the invasion cycle. Plant monitoring is performed by refuge personnel, partners, and cooperators as budgets allow and is greatly facilitated by a comprehensive plant list.

In addition to a plant list, refuge personnel often seek plant information that would assist them in meeting their management goals. Useful plant information might include wildlife use, wetland affinity, and key characters that allow differentiating species in the field. These data can be compiled from existing publications. 
From March 2011 to March 2012, the U.S. Geological Survey in cooperation with the U.S. Fish and Wildlife Service collected, identified, and photographed the vascular plants occurring at Caddo Lake National Wildlife Refuge (NWR), Texas. The goal of this project was to identify all vascular plant species occurring at Caddo Lake NWR and to take original photographs of each species while synthesizing information on field identification traits and wildlife use.

\section{Description of Study Area}

Caddo Lake NWR is located in Harrison County, Tex., on lands transferred in October 2000 from the Department of Defense, formerly the Longhorn Army Ammunition Plant (fig. 1). The refuge was established on the less contaminated portions of the retired munitions facility for the purpose of converting the site to habitat for birds, fish, and other wildlife. The 3,440-hectare refuge is divided by three drainages, Goose Prairie Creek, Central Creek, and Harrison Bayou, that flow north and east into Caddo Lake (U.S. Fish and Wildlife Service, 2012). It is located in the pineywoods vegetation area of northeast Texas (Hatch and others, 1990). A rolling ridge and swale landscape, created by these drainages, provides a variety of forest types and wetlands in this ancient drowned river valley.

Caddo Lake, a 10,850-hectare cypress swamp, borders the refuge on its eastern boundary (fig. 1). The soils are primarily sandy loams with clay-loam occurring in the drain bottoms. Forest types range from baldcypress (Taxodium distichum var. distichum) in the lower parts of Harrison Bayou to mixed pine-hardwoods on the slopes and pinedominated uplands. Shortleaf pine (Pinus echinata) savanna is thought to have been the dominant plant community on the highest elevations of the refuge, but these areas have largely been reforested with loblolly pine (Pinus taeda). Refuge management goals include restoring shortleaf pine savanna by selective logging of loblolly pine and hardwoods.

\section{Methods}

Field trips were made monthly from March 2011 to March 2012. Areas with variable hydrology, slope, elevation, and history were identified from maps and interviews with refuge personnel to select prospective sites for floristic surveys. Selected areas were explored during each sampling trip along with additional areas as time allowed. Individual plants were photographed in the field, and plant specimens were collected for laboratory inspection when identity was uncertain. Voucher specimens are housed at the U.S. Geological Survey National Wetlands Research Center Herbarium in Lafayette, Louisiana. Plant identifications were validated by using Correll and Johnston (1979), Flora of North America Editorial Committee (1993+), and various other manuals. Whether or not a species had been recorded for Harrison County, Tex., was based on collection location maps in the U.S. Department of Agriculture (USDA) PLANTS database (http://plants.usda.gov/). Plant morphological characters found to be diagnostic in field identification were photographed for illustration purposes (fig. 2). Images were organized and labeled by species scientific names based on the Integrated Taxonomic Information System (http://www.itis. gov/). Animals were photographed when encountered. Animal images were cataloged by scientific name when known and by common name when not. Insect identification was accomplished by using Arnett (1993) and BugGuide (2012).

\section{Results}

In the course of this study, 792 plant specimens were collected, identified, and labeled. More than 10,000 plant photographs and 622 animal photographs were taken at the refuge. The photograph collection in this report includes more than 1,600 select plant, animal, and landscape images (all photographs by Larry Allain).

This floristic inventory resulted in the identification of 511 taxa of vascular plants representing 111 families and 317 genera (table 1 at end of report). Phylogenetic families representing the greatest species count or diversity were the Asteraceae with 68, Poaceae with 62, Fabaceae with 43, Cyperaceae with 30, Rosaceae with 16, Rubiaceae with 14, Euphorbiaceae with 12, Lamiaceae with 12, Onagraceae with 12, Apiaceae with 10, and Scrophulariaceae with 9 species. The genera with the most species were Carex with 13, Juncus with 9, Quercus with 8, Ludwigia with 7, Paspalum with 7, and Polygonum with 6 species. 


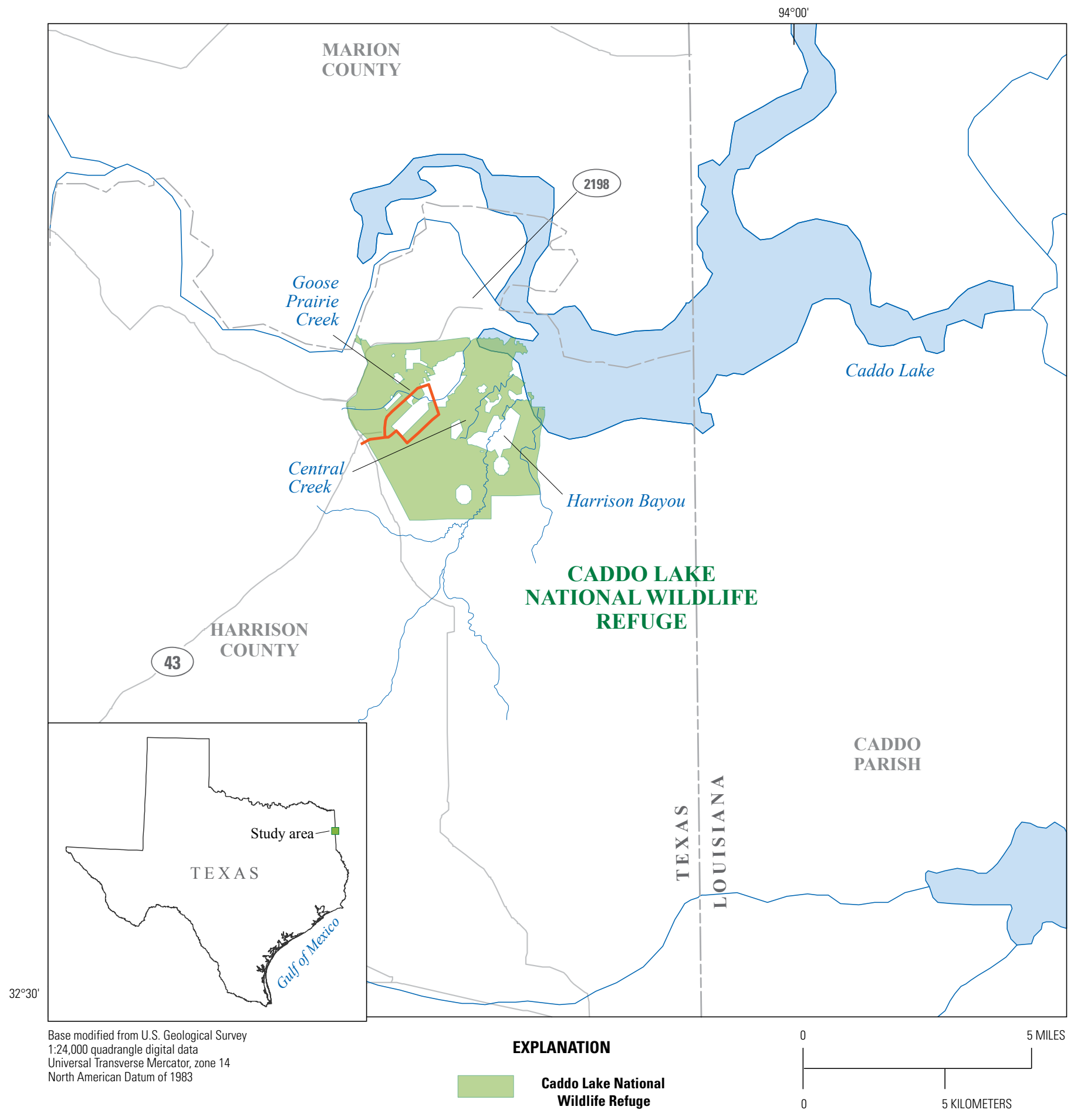

Auto Route

Figure 1. Location of Caddo Lake National Wildlife Refuge, Texas. 


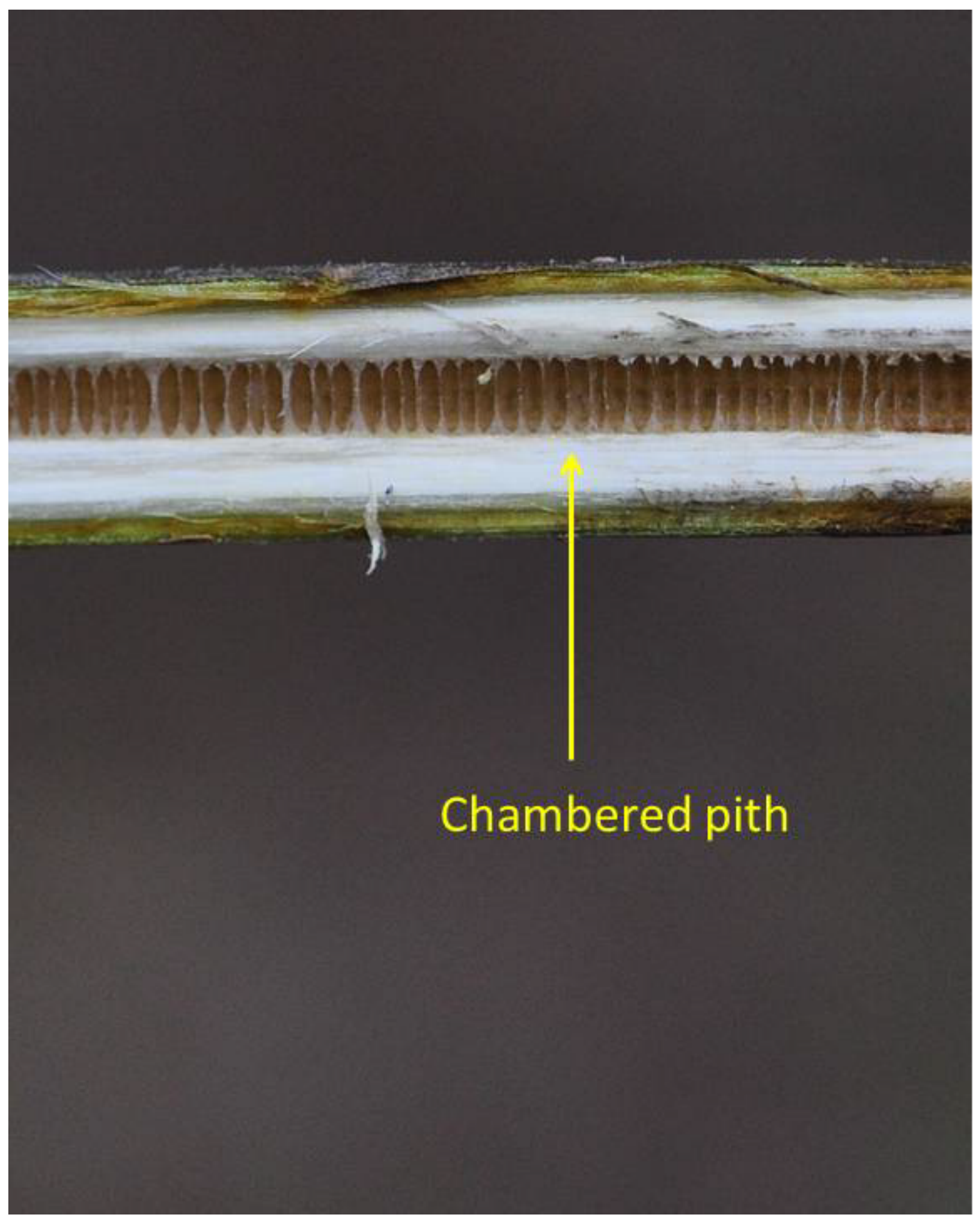

Figure 2. Chambered pith of black walnut (Juglans nigra), an example of diagnostic plant characters photographed during this project at Caddo Lake National Wildlife Refuge, Texas. Compound leaves of this tree are similar to leaves of hickories (Carya spp.), which can be distinguished by having solid pith in their twigs. 
Of the 511 species identified in this study, 346 are new records for Harrison County. According to the USDA PLANTS database, three species, peelbark St. Johnswort (Hypericum fasciculatum), changing forget-me-not (Myosotis discolor), and pond cypress (Taxodium distichum var. imbricarium) (fig. 3), are new to Texas. One species, Scleria ciliata var. ciliate, is listed for Texas by Hatch and others (1990) and one species, Pyrus calleryana, by Correll and Johnston (1979), but no locations are listed in the USDA PLANTS database for these two species.

Most of Caddo Lake NWR is forested with 56 tree species and 33 shrub species identified in this study. Forest types vary from pine forests on ridge tops to baldcypress swamp flooded forests in creek bottoms and within the frequently flooded sites near Caddo Lake. Pine-hardwood forest dominates on slopes and much of the upland and well-drained areas of Caddo Lake NWR (fig. 4). In pinehardwood forest, loblolly and shortleaf pine occur in association with such hardwood species as southern red oak (Quercus falcata), post oak (Quercus stellata), sweetgum (Liquidambar styraciflua), water oak (Quercus nigra), willow oak (Quercus phellos), white oak (Quercus alba), sugarberry (Celtis laevigata), blackgum (Nyssa sylvatica), and winged elm (Ulmus alata). Common understory shrub species in pine-hardwood forest include hawthorns (Crataegus sp.), American holly (Ilex opaca), waxmyrtle (Morella cerifera), farkleberry (Vaccinium arboreum), red buckeye (Aesculus pavia), flowering dogwood (Cornus florida), eastern redbud (Cercis canadensis), sassafras (Sassafras albidum), southern sugar maple (Acer barbatum), and American beautyberry (Callicarpa americana). Those species most common in ground cover vegetation are sedges (Carex spp. and Cyperus spp.), tick trefoil (Desmodium spp.), elephantsfoot (Elephantopus spp.), woodoats (Chasmanthium spp.), and panicums (Panicum spp. and Dichanthelium spp.). On the forest edge, vines predominate, with peppervine (Ampelopsis arborea), Virginia creeper (Parthenocissus quinquefolia), Alabama supplejack (Berchemia scandens), greenbriars (Smilax spp.), poison ivy (Toxicodendron radicans), and grapes (Vitis spp.) being most common.

Tree species that occurred in low areas along creek drainages and in frequently flooded parts of the refuge include baldcypress, overcup oak (Quercus lyrata), water oak, willow oak, green ash (Fraxinus pennsylvanica), bitter pecan (Carya aquatica), and sweetgum (fig. 5). Common smaller trees and shrubs include planertree (Planera aquatica), swamp privet (Forestiera acuminata), water locust (Gleditsia aquatic), buttonbush (Cephalanthus occidentalis), and possumhaw (Ilex decidua). Herbaceous ground cover in wet areas included mostly sedges, rushes (Juncus spp.), smartweeds (Persicaria spp.), heliotrope (Heliotropium indicum), camphorweeds (Pluchea spp.), lizard's tail (Saururus cernuus), primrosewillows (Ludwigia spp.), and rosemallow (Hibiscus moscheutos ssp. lasiocarpos). Vines most common in these areas were climbing hempvine (Mikania scandens), buckwheat vine (Brunnichia ovata), and climbing dogbane (Thyrsanthella difformis).

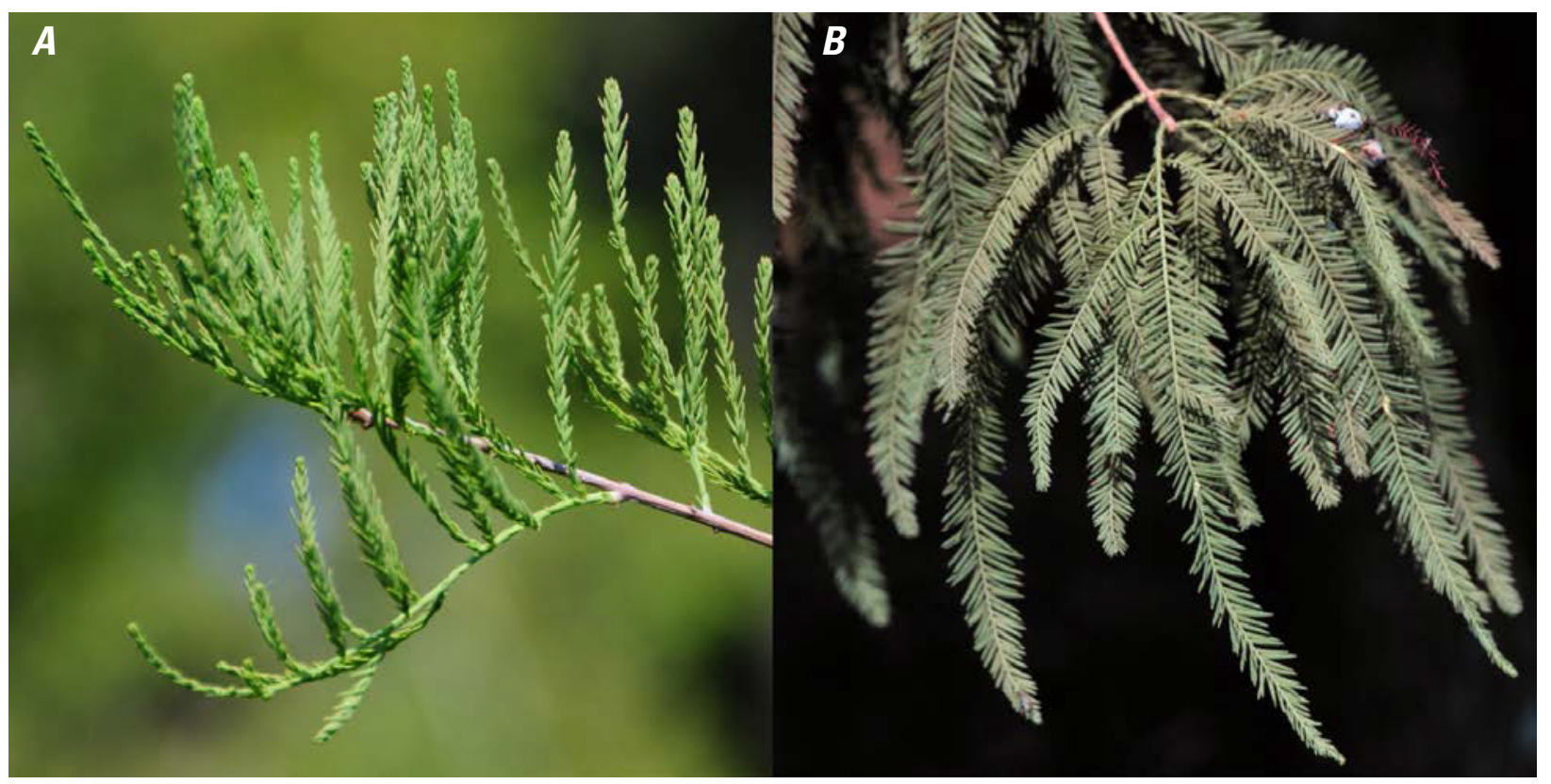

Figure 3. The differences in leaf form of two varieties of Taxodium distichum occurring on Caddo Lake National Wildlife Refuge, Texas. $A$, Taxodium distichum var. imbricarium, a new taxon for Texas, has scale-like leaflets on upward oriented leaves. $B$, Taxodium distichum var. distichum has descending leaves and linear leaflets. 


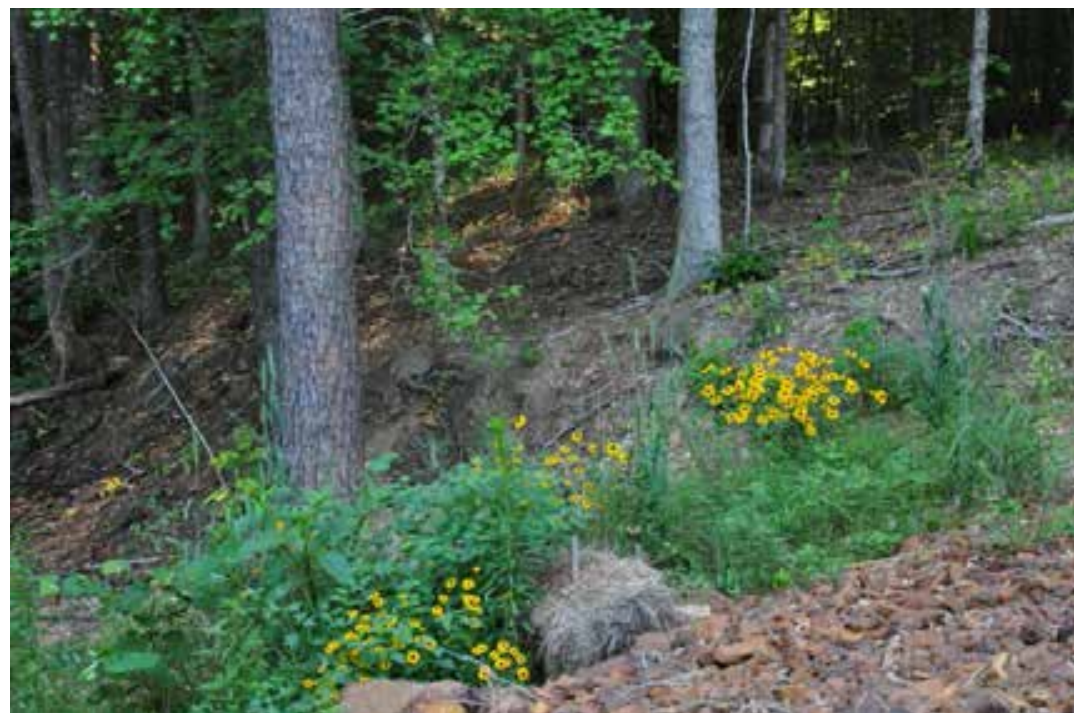

Figure 4. Pine-hardwood forest predominant on slopes and other well-drained sites in Caddo Lake National Wildlife Refuge, Texas.

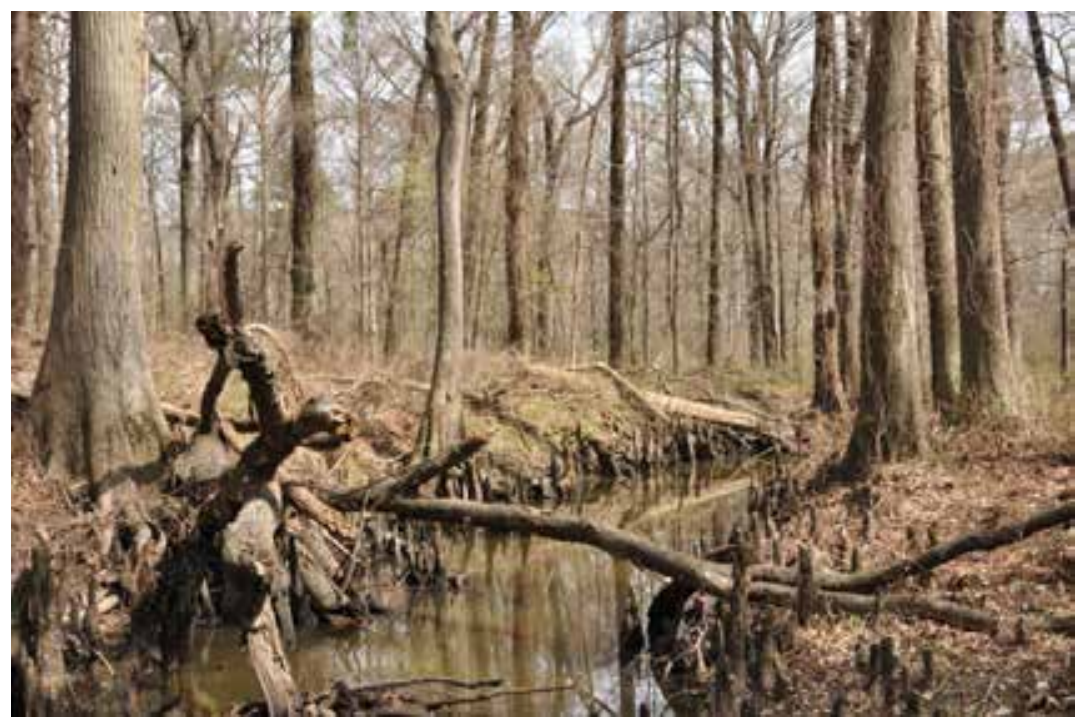

Figure 5. Bottomland hardwoods dominated by baldcypress (Taxodium distichum var. distichum) along drainages and in frequently flooded parts of Caddo Lake National Wildlife Refuge, Texas. 
Many of the vascular plants that occur in shortleaf pine understory were present on the refuge, but most were uncommon. Grasses, growing mostly on roadsides and that are associated with savanna understory, include splitbeard bluestem (Andropogon ternarius), woodoats, little bluestem (Schizachyrium scoparium), switchgrass (Panicum virgatum), prairie panicgrass (Panicum brachyanthum), brownseed paspalum (Paspalum plicatulum), eastern gamagrass (Tripsacum dactyloides), purpletop (Tridens flavus), arrowfeather three-awn (Aristida purpurascens), and rosette grasses (Dichanthelium spp.). Several conservative species usually confined to undisturbed shortleaf pine understory and prairies were identified, including nodding lady's tresses (Spiranthes cernua), dwarf sundew (Drosera brevifolia), and pinkscale blazing star (Liatris elegans). Other wildflowers of pine savanna occurred in small populations such as sidebeak pencilflower (Stylosanthes biflora), diamond flowers (Stenaria nigricans), multibloom hoarypea (Tephrosia onobrychoides), roughleaf coneflower (Rudbeckia grandiflora), hairyflower spiderwort (Tradescantia hirsutiflora), Carolina anemone (Anemone caroliniana), groovestem Indian plantain (Arnoglossum plantagineum), and butterfly milkweed (Asclepias tuberosa).

Wetland indicator status (Lichvar, 2013) of the taxa identified in this study indicated that most of the species are wetland plants, possibly reflecting the proximity of Caddo Lake and the three streams that intersect the refuge. While 222 species were categorized as upland or facultative upland plants, 289 are associated with wetlands with 122 facultative, 78 facultative wet, and 82 obligate wetland species.

Of the 511 taxa identified in this study, 62 were introduced (table 2 at end of report). Most nonnative species have become naturalized and make up a small part of the flora, although several are invasive and pose a risk to native vegetation and wildlife habitat quality. Chinese tallow tree (Triadica sebifera) is highly invasive and is a management priority for refuge staff (figs. 6 and 7). Other nonnative trees including flowering pear (Pyrus calleryana), silk tree (Albizia julibrissin), and Chinaberry tree (Melia azedarach) are

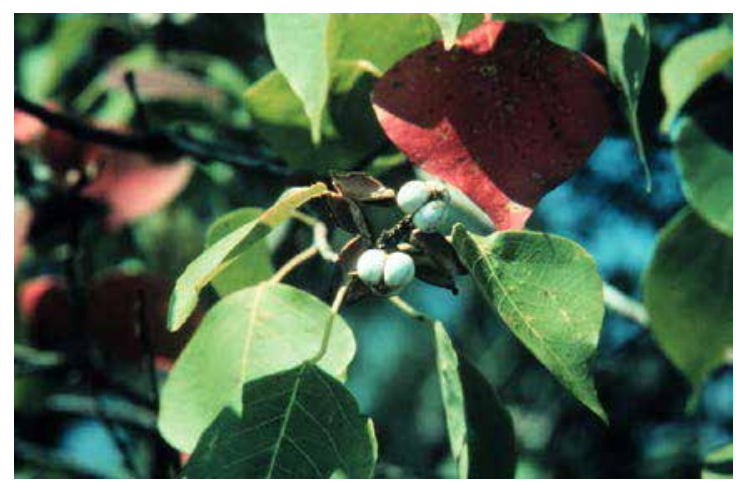

Figure 6. Chinese tallow tree (Triadica sebifera), an invasive nonnative species that is currently controlled by refuge management at Caddo Lake National Wildlife Refuge, Texas. Pictured here in the fall of the year is a branch bearing white seeds and leaves beginning to turn colors.

present but do not appear to pose a risk of becoming invasive. Chinese privet (Ligustrum sinense) is present and has not yet become invasive at Caddo Lake NWR. Elsewhere in east Texas forests, Chinese privet has become a nuisance invader in forest understory. Another understory shrub with a history of invasion, sacred bamboo (Nandina domestica), was rare on the refuge but should be part of an active eradication program (fig. 8). While numerous nonnative forbs and grasses bloom on the roadsides of Caddo Lake NWR, one grass species is problematic. King's Ranch bluestem or KR bluestem (Bothriochloa ischaemum var. songarica) has spread eastward and northward from south Texas along roadsides in the past 15-20 years colonizing disturbed grasslands, roadsides, and old agricultural fields. Mowing may speed its spread, and it has the potential to exclude other species. Without a control strategy, the diverse and colorful variety of wildflowers lining the roads at Caddo Lake NWR may become a monoculture of KR bluestem. 


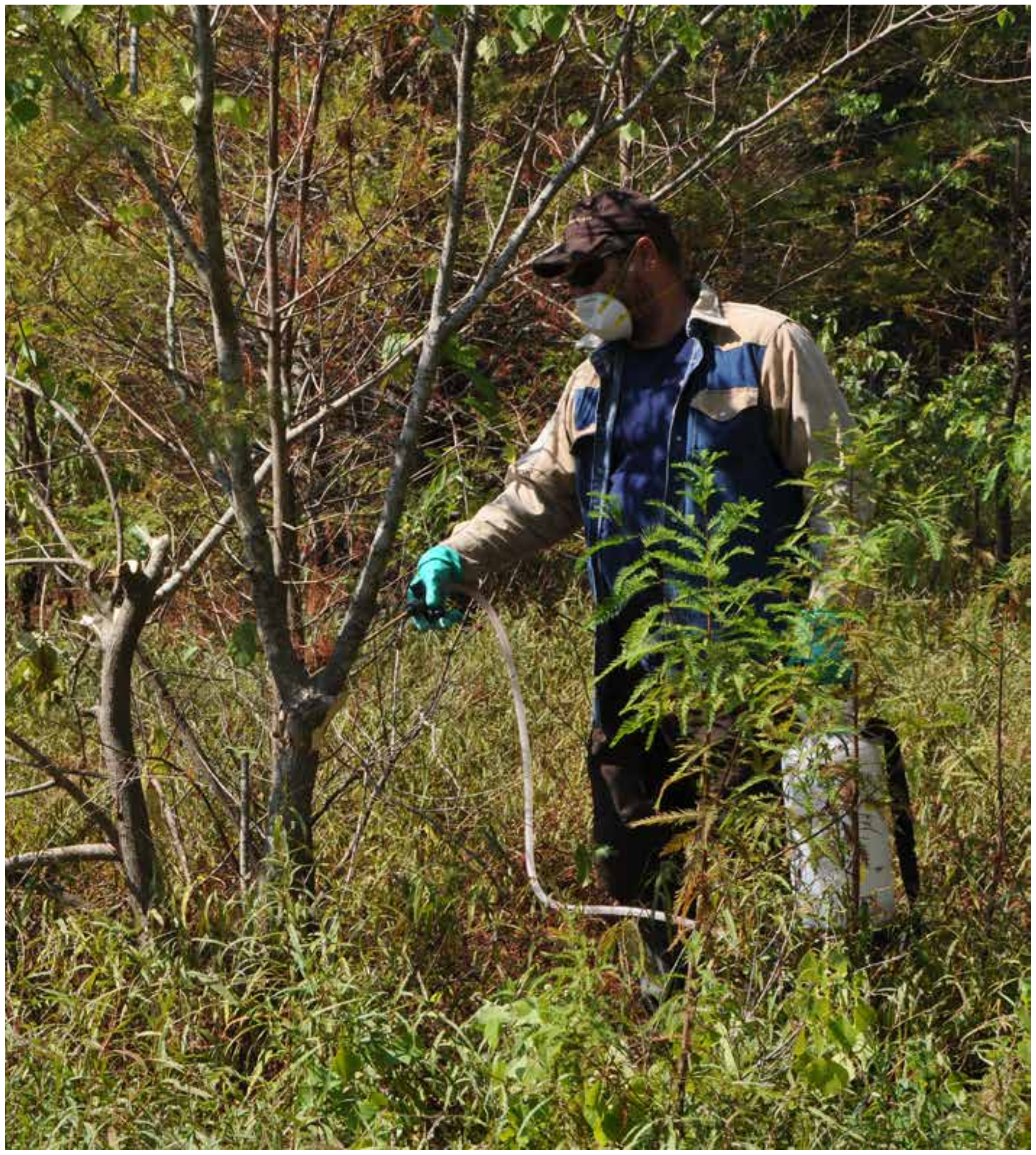

Figure 7. Staff of Caddo Lake National Wildlife Refuge, Texas, using herbicide to treat small Chinese tallow trees (Triadica sebifera) before these nonnative, highly invasive trees can bear seeds and colonize additional area. 


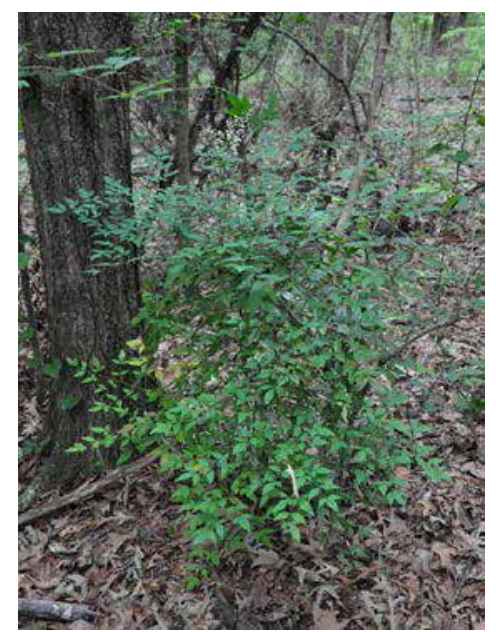

Figure 8. An invasive understory shrub, sacred bamboo (Nandina domestica), that was collected on a small outholding of Caddo Lake National Wildlife Refuge, Texas, north of Texas Farm to Market Road 2198 (FM 2198).

Giant salvinia (Salvinia molesta), considered one of the world's worst aquatic pests (Oliver, 1993), has become a major problem in Caddo Lake (fig. 9). A native of Brazil (Everitt and others, 2007), giant salvinia impedes navigation and reduces sunlight and oxygen, killing beneficial plants, insects, and fish. It can clog agricultural irrigation ditches

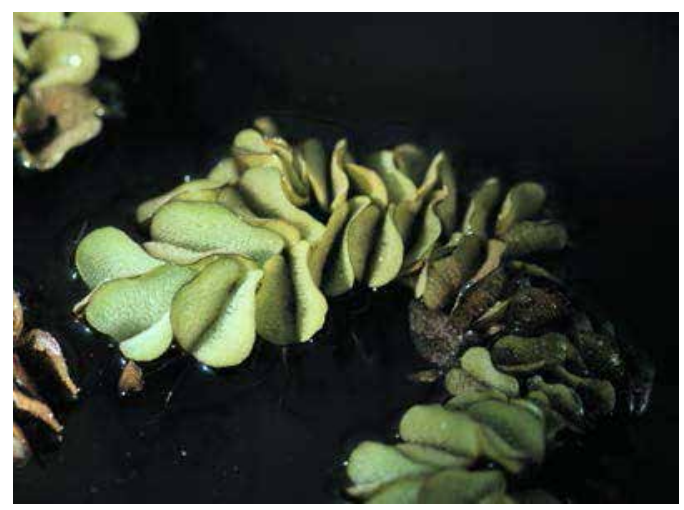

Figure 9. Giant salvinia (Salvinia molesta), considered one of the world's worst aquatic pests. It has become a major problem on Caddo Lake at Caddo Lake National Wildlife Refuge, Texas. and impair electrical generation (Holm and others, 1977). Experimental research is being conducted by the Caddo Lake Institute in cooperation with Caddo Lake NWR to investigate the use of a beetle (Cyrtobagous salviniae) for biological control of this aggressive weed.

In addition to wild species, planted species were also collected and photographed during this project. A live oak tree (Quercus virginiana) apparently planted as a landscape specimen near the refuge office was the only individual of that species occurring on the refuge. Indian paintbrush (Castilleja indivisa) and firewheel (Gaillardia pulchella) growing on the roadside at the entrance of the refuge are commonly planted on roadsides in Texas and were not found elsewhere on the refuge. A combination of plant species including Illinois bundleflower (Desmanthus illinoensis), plains snakecotton (Froelichia floridana), and Maximilian sunflower (Helianthus maximiliani) dominated the road median in front of the refuge office and was reported to be the results of a grassland planting conducted by Texas Parks and Wildlife Department (Jason Roesner, assistant refuge manager, oral commun., 2011). Plant species thought to have been planted are labeled in table 1.

\section{Discussion}

Despite the developed nature of the Longhorn Army Ammunition Plant at the time it was transferred to the U.S. Fish and Wildlife Service, considerable plant diversity can be found at the refuge. Forest types range from pine-hardwood on ridges to cypress-dominated bottomland hardwoods along the three drainages and the lake margin. Diverse communities of herbaceous plant species on roadsides and in forest clearings include remnant species common in predevelopment plant communities, as well as ruderal species.

In the wettest areas of the refuge, plants such as smartweeds (Persicaria spp.) and primrose willows (Ludwigia spp.) provide food for overwintering waterfowl (table 3 at end of report). Diverse grassy areas provide quality habitat for grassland species. Occasional deer, wild turkeys, northern bobwhite (Colinus virginianus), eastern cottontail (Sylvilagus floridanus), coyote (Canis spp.), gray (Sciurus carolinensis) and fox (Sciurus niger) squirrels, and numerous other animals can be glimpsed along the Auto Route (a 6-mile-long auto tour through a small portion of the refuge; fig. 1). At the western end of their range at Caddo Lake NWR, three-toed box turtles (Terrapene carolina triunguis) can sometimes be seen in open forest or on roadsides, especially during their March and April breeding season (fig. 10). 


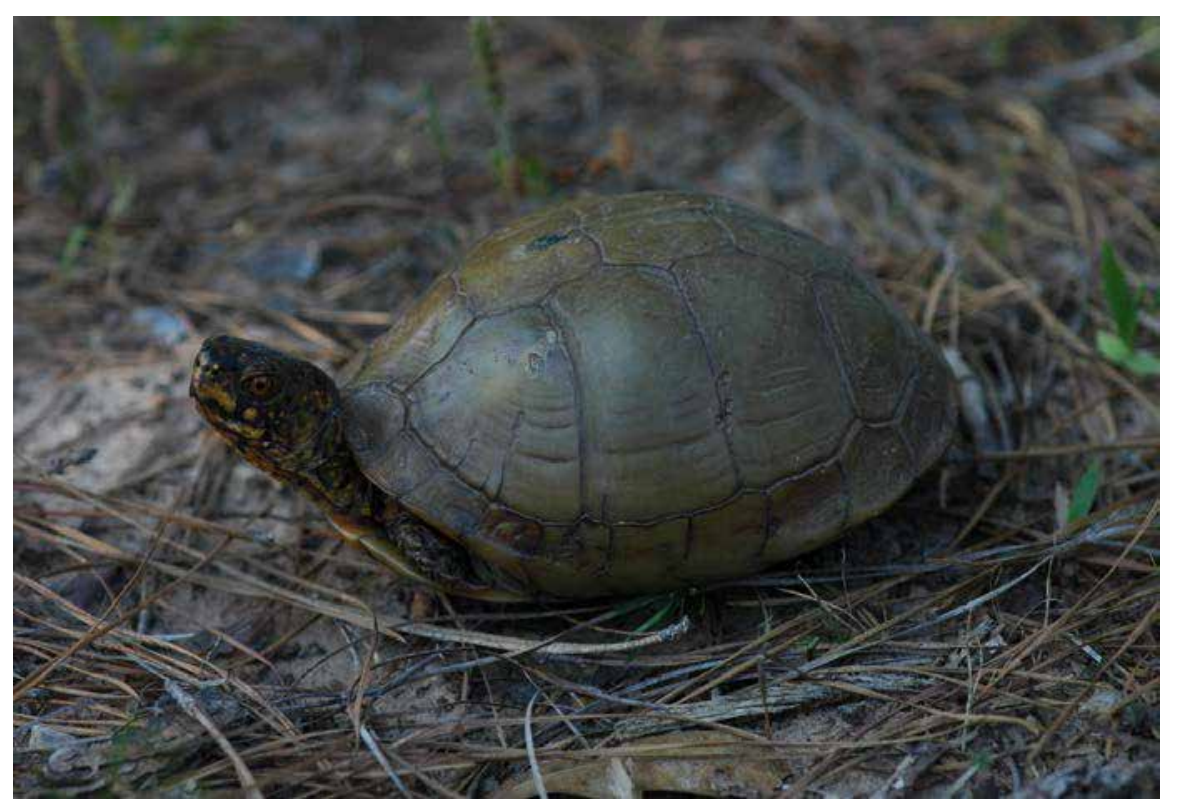

Figure 10. A three-toed box turtle (Terrapene carolina triunguis), so named because of the number of toes on the back feet, at Caddo Lake National Wildlife Refuge, Texas. Their range extends from east Texas to the Florida Panhandle.

Numerous species of birds reside year-round or migrate through the refuge during spring and fall including eastern bluebird (Sialia sialis), American woodcock (Scolopax minor), yellow-breasted chat (Icteria virens), rufous-sided towhee (Pipilo erythrophthalmus), and white-throated sparrow (Zonotrichia albicollis). Butterflies and numerous other insects can be seen along the roadsides in spring and fall (fig. 11). Widening of grassy areas along the refuge's Auto Route and other interior roads could provide additional habitat for native pollinators and other grassland insect species.

Roadsides within the refuge provide a colorful show of wildflowers. Trees, with their leaf, flower, and seed displays, create a vivid natural experience for visitors. Many of the species listed as constituents of shortleaf pine understory are present on the refuge and could be restored as part of the refuge's goal of restoring shortleaf pine savanna. Such a restoration strategy would enhance the value of these forests for wildlife, as well as create a more rewarding experience for refuge visitors.

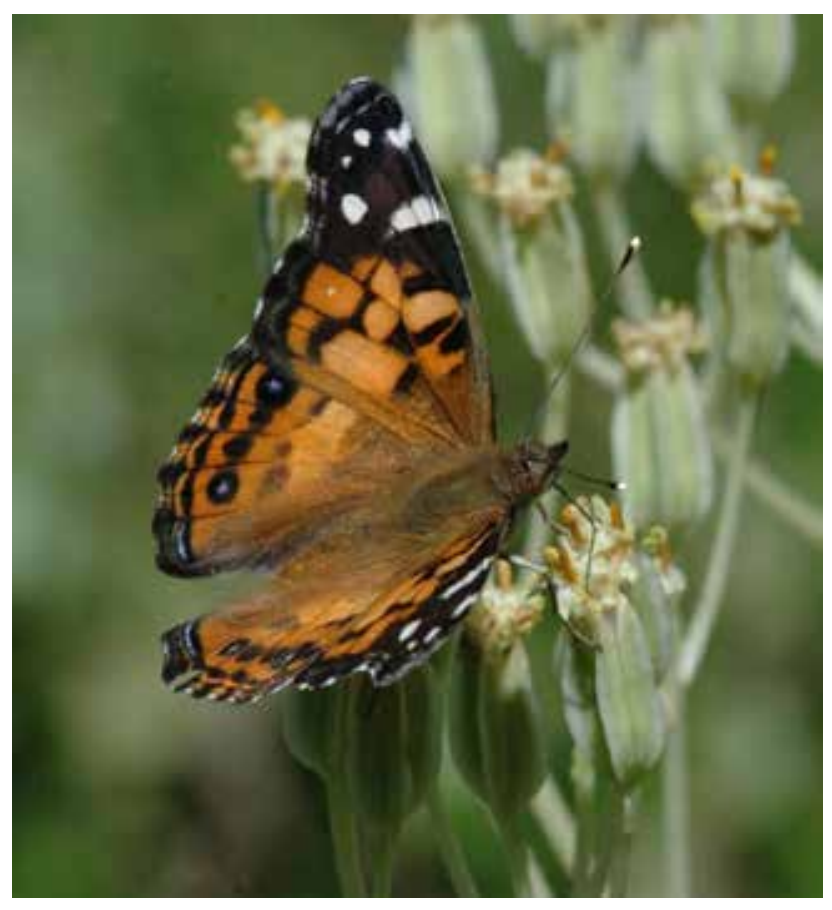

Figure 11. American lady butterfly (Vanessa virginiensis) nectering on the flowers of groovestem Indian plantain (Arnoglossum plantagineum) on a roadside along the Auto Route in Caddo Lake National Wildlife Refuge, Texas. A wide variety of butterflies and skippers occur on the refuge. 


\section{Summary}

From March 2011 to March 2012, vascular plants were collected and photographed at Caddo Lake National Wildlife Refuge (NWR), Texas, to produce a floristic inventory. The goal of this project was to create both a comprehensive list of the refuge's vascular flora and a photographic record of each plant species. This plant inventory resulted in the identification of 511 taxa of vascular plants representing 111 families and 317 genera. Of the species identified in this study, 346 are new records for Harrison County. Caddo Lake NWR is primarily forested with 56 tree species and 33 shrub species identified in this study. Of the plant species identified, 289 are associated with wetlands having a wetland classification of facultative or wetter. Sixty-two of the species found on the refuge are introduced, including the invasive Chinese tallow tree (Triadica sebifera), Chinese privet (Ligustrum sinense), sacred bamboo (Nandina domestica), and King's Ranch bluestem (Bothriochloa ischaemum var. songarica). More than 10,000 photographs were taken of plants found on the refuge in an effort to document general appearance, as well as the diagnostic characters of each plant species. Photographs were also taken of wildlife encountered during the collective field trips. Of the photographs taken, more than 1,600 select digital images of plants, animals, and landscapes are included in the photograph collection (all photographs by Larry Allain).

\section{Acknowledgments}

I thank John McCoy and Richard Day, U.S. Geological Survey, for field support and comments.

\section{References Cited}

Arnett, R.H., Jr., 1993, American insects-A handbook of the insects of America north of Mexico: Gainesville, Fla., The Sandhill Crane Press, Inc., $850 \mathrm{p}$.

Blair, R.M., and Brunett, L.E., 1980, Seasonal browse selection by deer in southern pine-hardwood habitat: Journal of Wildlife Management, v. 44, no. 1.

BugGuide, 2012, BugGuide-Identification, images, \& information for insects, spiders $\&$ their kin for the United States \& Canada: Accessed January 23, 2012, at http://bugguide.net/.
Correll, D.S., and Johnston, M.C., 1979, Manual of the vascular plants of Texas: The University of Texas at Dallas, $1,880 \mathrm{p}$.

Everitt, J.H., Lonard, R.L., and Little, C.R., 2007, Weeds in south Texas and northern Mexico: Lubbock, Texas Tech University Press, $240 \mathrm{p}$.

Flora of North America Editorial Committee, eds., 1993+, Flora of North America-North of Mexico: New York, Oxford University Press, $16+v$.

Hatch, S.L., Gandhi, K.N., and Brown, L.E., 1990, Checklist of the vascular plants of Texas: College Station, Texas Agricultural Experiment Station, 158 p.

Holm, L.G., Plucknett, D.L., Pancho, J.V., and Herberge, J.P., 1977, The world's worst weeds: Honolulu, University Press of Hawaii, 609 p.

Lay, D.W., 1969, Foods and feeding habits of white-tailed deer, in Halls, L.K., ed., White-Tailed Deer in the Southern Forest Habitat, Proceedings of a Symposium: Nacogdoches, Tex., U.S. Department of Agriculture Forest Service, Southern Forest Experiment Station, p. 8-13.

Lichvar, R.W., 2013, The national wetland plant list-2013 wetland ratings: Phytoneuron, v. 2013, no. 49, p. 1-241, accessed January 24, 2012, at http://www.phytoneuron.net/.

Miller, J.H., and Miller, K.V., 2005, Forest plants of the southeast and their wildlife uses: Athens, The University of Georgia Press, 454 p.

Oliver, J.D., 1993, A review of the biology of giant salvinia (Salvinia molesta Mitchell): Journal of Aquatic Plant Management, v. 31, p. 227-231.

Stutzenbeaker, C.D., 1999, Aquatic and wetland plants of the western Gulf Coast: Texas Parks and Wildlife Press, 465 p.

U.S. Fish and Wildlife Service, 2012, Caddo Lake National Wildlife Refuge, Texas-About the refuge: Accessed December 19, 2011, at http://www.fws.gov/refuge/Caddo Lake/about.html.

U.S. Fish and Wildlife Service, 2013, National Wildlife Refuge System-Overview: Accessed January 21, 2014, at http://www.fws.gov/refuges/about/pdfs/ OverviewFactSheetApril2013.pdf. 
Table 1. Comprehensive list of vascular plants identified at Caddo Lake National Wildlife Refuge, Texas, March $2011-M a r c h ~ 2012$.

[E, exotic species; P, planted species; N, new record for Harrison County, Texas. Wetland classifications (Lichvar, 2013) are listed as follows: OBL, obligate wetland; FACW, facultative wetland; FAC, facultative; FACU, facultative upland; UP, obligate upland]

\begin{tabular}{ccc}
\hline Family & Scientific name and authority [wetland classification] & Common name \\
\hline Ferns &
\end{tabular}

Aspleniaceae

Asplenium platyneuron (L.) Britton, Sterns \& Poggenb. [FACU]

ebony spleenwort

Dennstaedtiaceae

Pteridium aquilinum (L.) Kuhn [FACU]

western brackenfern

Dryopteridaceae

Onoclea sensibilis L. [FACW]

Polystichum acrostichoides (Michx.) Schott [FACU]

Woodsia obtusa (Spreng.) Torr. [UPL]

Ophioglossaceae

Botrychium virginianum (L.) Sw. [FACU]

Polypodiaceae

Pleopeltis polypodioides (L.) E.G. Andrews \& Windham [FAC]

Salviniaceae

Salvinia molesta D.S. Mitch. [E, N,OBL]

Gymnosperms

Cupressaceae

Juniperus virginiana L. [FACU]

Taxodium distichum var. imbricarium (Nutt.) Croom [N, OBL]

Taxodium distichum var. distichum (L.) Rich. [OBL]

Pinaceae

Pinus echinata Mill. [UPL]

Pinus palustris Mill. [P, N, FAC]

Pinus taeda L. [FAC] sensitive fern

Christmas fern

bluntlobe cliff fern

rattlesnake fern

resurrection fern

kariba-weed eastern redcedar

pond cypress

baldcypress shortleaf pine

longleaf pine

loblolly pine

Monocots

Alismataceae

Echinodorus cordifolius (L.) Griseb. [OBL]

Sagittaria platyphylla (Engelm.) J.G. Sm. [N, OBL]

Amaryllidaceae

Allium canadense var. mobilense (Regel) Ownbey [N, FACU]

Lycoris radiata (L'Hér.) Herb. [E, P, N, UPL]

Narcissus jonquilla L. [E, P, N, UPL]

Nothoscordum bivalve (L.) Britton [N, FACU]

Arecaceae

Sabal minor (Jacq.) Pers. [N, FACW]

Araceae

Arisaema dracontium (L.) Schott [FACW]

Spirodela polyrrhiza (L.) Schleid. [OBL]

Wolffia columbiana H. Karst. [OBL] creeping burhead

delta arrowhead

Mobile meadow garlic

red spider lily

jonquil

crowpoison

dwarf palmetto

green dragon

common duckmeat

Columbian watermeal 
Table 1. Comprehensive list of vascular plants identified at Caddo Lake National Wildlife Refuge, Texas, March 2011-March 2012. -Continued

[E, exotic species; P, planted species; N, new record for Harrison County, Texas. Wetland classifications (Lichvar, 2013) are listed as follows: OBL, obligate wetland; FACW, facultative wetland; FAC, facultative; FACU, facultative upland; UP, obligate upland]

\begin{tabular}{ccc}
\hline Family & Scientific name and authority [wetland classification] & Common name \\
\hline Monocots-Continued &
\end{tabular}

Asparagaceae

Yucca louisianensis Trel. [N, UPL]

Gulf Coast yucca

Bromeliaceae

Tillandsia usneoides (L.) L. [FAC]

Spanish moss

Commelinaceae

Commelina communis L. [E, N, FAC]

Commelina virginica $\mathrm{L}$. [N, FACW]

Tradescantia hirsutiflora Bush [N, UPL]

Tradescantia ohiensis Raf. [N, FAC]

Cyperaceae

Carex blanda Dewey [N, FAC]

Carex caroliniana Schwein. [N, FACW]

Carex cephalophora Muhl. ex Willd. [N, FAC]

Carex cherokeensis Schwein. [N, FACW]

Carex complanata Torr. \& Hook. [FAC]

Carex hyalinolepis Steud. [N, OBL]

Carex longii Mack. [N, OBL]

Carex lupulina Muhl. ex Willd. [N, OBL]

Carex lurida Wahlenb. [OBL]

Carex oxylepis Torr. \& Hook. [N, FACW]

Carex reniformis (L.H. Bailey) Small [N, FACW]

Carex triangularis Boeckeler [FACW]

Carex vulpinoidea Michx. [FACW]

Cyperus acuminatus Torr. \& Hook. ex Torr. [N, OBL]

Cyperus echinatus (L.) Alph. Wood [FAC]

Cyperus odoratus L. [N, FACW]

Cyperus pseudovegetus Steud. [FACW]

Cyperus retrorsus Chapm. [N, FACU]

Cyperus strigosus L. [N, FACW]

Cyperus virens Michx. [N, FACW]

Eleocharis macrostachya Britton [N, OBL]

Eleocharis obtusa (Willd.) Schult. [OBL]

Fimbristylis vahlii (Lam.) Link [OBL]

Isolepis carinata Hook. \& Arn. ex Torr. [OBL]

Rhynchospora caduca Elliott [N, OBL]

Rhynchospora corniculata (Lam.) A. Gray [N, OBL]

Rhynchospora harveyi W. Boott [N, FACW]

Scirpus cyperinus (L.) Kunth [N, OBL]

Scleria ciliata var. ciliata Michx. [N, FAC]

Scleria oligantha Michx. [FAC]

Iridaceae

Iris albicans J. Lange [E, N, UPL]

Sisyrinchium atlanticum E.P. Bicknell [N, FACW]

Sisyrinchium langloisii Greene [N, UPL]
Asiatic dayflower

Virginia dayflower

hairyflower spiderwort

bluejacket

eastern woodland sedge

Carolina sedge

oval-leaf sedge

Cherokee sedge

blue sedge

shoreline sedge

Long's sedge

hop sedge

shallow sedge

sharpscale sedge

kidneyshape sedge

eastern fox sedge

fox sedge

tapertip flatsedge

globe flatsedge

fragrant flatsedge

marsh flatsedge

pine barren flatsedge

strawcolored flatsedge

green flatsedge

pale spikerush

blunt spikerush

Vahl's fimbry

keeled bulrush

anglestem beaksedge

shortbristle horned beaksedge

Harvey's beaksedge

woolgrass

fringed nutrush

littlehead nutrush

cemetery iris

eastern blue-eyed grass

roadside blue-eyed grass 
Table 1. Comprehensive list of vascular plants identified at Caddo Lake National Wildlife Refuge, Texas, March 2011-March 2012. -Continued

[E, exotic species; P, planted species; N, new record for Harrison County, Texas. Wetland classifications (Lichvar, 2013) are listed as follows: OBL, obligate wetland; FACW, facultative wetland; FAC, facultative; FACU, facultative upland; UP, obligate upland]

\begin{tabular}{|c|c|c|}
\hline Family & Scientific name and authority [wetland classification] & Common name \\
\hline \multicolumn{3}{|c|}{ Monocots-Continued } \\
\hline \multicolumn{3}{|l|}{ Juncaceae } \\
\hline & Juncus bufonius L. [FACW] & toad rush \\
\hline & Juncus dichotomus Elliott [FACW] & forked rush \\
\hline & Juncus diffusissimus Buckley [FACW] & slimpod rush \\
\hline & Juncus effusus L. [N, OBL] & common rush \\
\hline & Juncus polycephalus Michx. [N, OBL] & manyhead rush \\
\hline & Juncus tenuis Willd. [N, FAC] & poverty rush \\
\hline & Juncus validus Coville [N, FACW] & roundhead rush \\
\hline
\end{tabular}

Orchidaceae

Spiranthes cernua (L.) Rich. [N, FACW]

nodding lady's tresses

Poaceae

Agrostis hyemalis (Walter) Britton, Sterns \& Poggenb. [N, FAC] Andropogon glomeratus (Walter) Britton, Sterns \& Poggenb. [FACW] Andropogon ternarius Michx. [FACU]

Andropogon virginicus L. [FAC]

Aristida oligantha Michx. [UPL]

Aristida purpurascens Poir. [N, FACW]

Arundinaria gigantea (Walter) Muhl. [FACW]

Axonopus fissifolius (Raddi) Kuhlm. [N, FACW]

Bothriochloa ischaemum var. songarica (Rupr. ex Fisch. \& Meyen)

Celarier \& J.R. Harlan [E, N, UPL]

Briza minor L. [E, FAC]

Bromus catharticus Vahl [E, N, UPL)

Chasmanthium latifolium (Michx.) H.O. Yates [FAC]

Chasmanthium laxum ssp. laxum (L.) H.O. Yates [FACW]

Chasmanthium laxum ssp. sessiliflorum (Poir.) L.G. Clark [N, FAC]

Coleataenia anceps (Michx.) Soreng [FAC]

Coleataenia longifolia ssp. rigidula (Bosc ex Nees) Soreng [FACW]

Cynodon dactylon (L.) Pers. [E, N, FACU]

Dichanthelium aciculare (Desv. ex Poir.) Gould \& C.A. Clark [N, FACU]

Dichanthelium acuminatum (Sw.) Gould \& C.A. Clark [FAC]

Dichanthelium commutatum (Schult.) Gould [N, FAC]

Dichanthelium scoparium (Lam.) Gould [FACW]

Dichanthelium sphaerocarpon (Elliott) Gould [FACU]

Digitaria ciliaris (Retz.) Koeler [N, FACU]

Digitaria ischaemum (Schreb.) Muhl. [E, N, UPL]

Digitaria sanguinalis (L.) Scop. [E, N, FACU]

Digitaria violascens Link [E, N, FAC]

Eleusine indica (L.) Gaertn. [E, FACU]

Elymus virginicus L. [E, FAC]

Eragrostis hypnoides (Lam.) Britton, Sterns \& Poggenb. [OBL]

Eragrostis spectabilis (Pursh) Steud. [FACU] winter bentgrass

bushy bluestem

splitbeard bluestem

broomsedge bluestem

prairie threeawn

arrowfeather three-awn grass

giant cane

common carpetgrass

King's Ranch bluestem

little quakinggrass

rescuegrass

Indian woodoats

slender woodoats

longleaf woodoats

beaked panicgrass

redtop panicgrass

Bermudagrass

needleleaf rosette grass

tapered rosette grass

variable panicgrass

velvet panicum

roundseed panicgrass

southern crabgrass

smooth crabgrass

hairy crabgrass

violet crabgrass

goosegrass

Virginia wildrye

teal lovegrass

purple lovegrass 
Table 1. Comprehensive list of vascular plants identified at Caddo Lake National Wildlife Refuge, Texas, March 2011-March 2012. -Continued

[E, exotic species; P, planted species; N, new record for Harrison County, Texas. Wetland classifications (Lichvar, 2013) are listed as follows: OBL, obligate wetland; FACW, facultative wetland; FAC, facultative; FACU, facultative upland; UP, obligate upland]

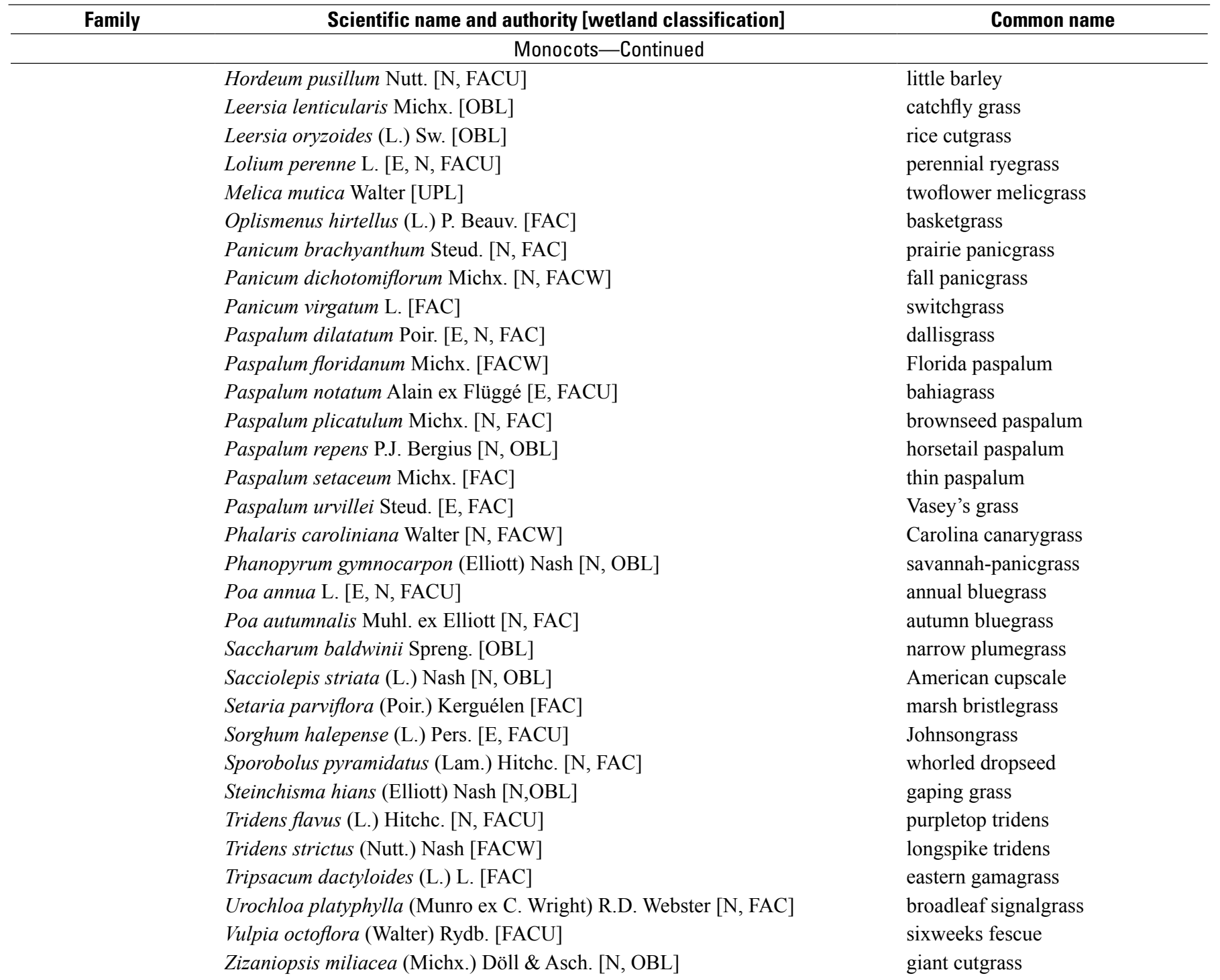

Pontederiaceae

Eichhornia crassipes (Mart.) Solms [E, OBL]

common water hyacinth

Smilacaceae

Smilax bona-nox L. [N, FAC]

Smilax glauca Walter [FAC]

Smilax rotundifolia $\mathrm{L}$. [FAC]

Smilax smallii Morong [N, FACU]

Smilax walteri Pursh [N, OBL]

Typhaceae saw greenbrier cat greenbrier roundleaf greenbrier lanceleaf greenbrier coral greenbrier

broadleaf cattail 
Table 1. Comprehensive list of vascular plants identified at Caddo Lake National Wildlife Refuge, Texas, March $2011-M a r c h ~ 2012$. -Continued

[E, exotic species; P, planted species; N, new record for Harrison County, Texas. Wetland classifications (Lichvar, 2013) are listed as follows: OBL, obligate wetland; FACW, facultative wetland; FAC, facultative; FACU, facultative upland; UP, obligate upland]

\begin{tabular}{ccc}
\hline Family & Scientific name and authority [wetland classification] & Common name \\
\hline & Dicots &
\end{tabular}

Acanthaceae

Justicia ovata (Walter) Lindau [N, OBL]

Ruellia caroliniensis (J.F. Gmel.) Steud. [N, FACU]

Ruellia humilis Nutt. [N, FACU]

Ruellia pedunculata Torr. ex A. Gray [UPL]

Adoxaceae

Sambucus nigra ssp. canadensis (L.) R. Bolli [N, FACW]

Altingiaceae

Liquidambar styraciflua L. [FAC]

Amaranthaceae

Alternanthera philoxeroides (Mart.) Griseb. [E, N, OBL]

Froelichia floridana (Nutt.) Moq. [N, UPL]

Anacardiaceae

Rhus copallinum L. [N, UPL]

Rhus glabra L. [N, UPL]

Toxicodendron radicans (L.) Kuntze [FAC]

Annonaceae

Asimina parviflora (Michx.) Dunal [N, FACU]

Apiaceae

Chaerophyllum tainturieri Hook. [N, FAC]

Cicuta maculata L. [N, OBL]

Daucus carota L. [N, UPL]

Eryngium yuccifolium Michx. [N, FAC]

Limnosciadium pinnatum (DC.) Mathias \& Constance [N, FACW]

Ptilimnium capillaceum (Michx.) Raf. [N, OBL]

Ptilimnium nuttallii (DC.) Britton [N, FAC]

Sanicula canadensis L. [N, FACU]

Trepocarpus aethusae Nutt. ex DC. [FACW]

Apocynaceae

Apocynum cannabinum L. [N, FAC]

Asclepias tuberosa L. [N, UPL]

Asclepias variegata $\mathrm{L}$. [FACU]

Asclepias verticillata L. [N, FACU]

Asclepias viridis Walter [N, UPL]

Matelea gonocarpos (Walter) Shinners [N, UPL]

Trachelospermum difforme (Walter) A. Gray [N, FACW]

Aquifoliaceae looseflower water-willow

Carolina wild petunia

fringeleaf wild petunia

stalked wild petunia

American elderberry

sweetgum

alligatorweed

plains snakecotton

winged sumac

smooth sumac

eastern poison ivy

smallflower pawpaw

hairyfruit chervil

spotted water hemlock

Queen Anne's lace

button eryngo

tansy dogshade

herbwilliam

laceflower

Canadian blacksnakeroot

whitenymph

Indian hemp butterfly milkweed redring milkweed whorled milkweed green antelopehorn angularfruit milkvine climbing dogbane

Carolina holly possumhaw
Ilex ambigua (Michx.) Torr. [N, UPL]

Ilex decidua Walter [FACW] 
Table 1. Comprehensive list of vascular plants identified at Caddo Lake National Wildlife Refuge, Texas, March 2011-March 2012. -Continued

[E, exotic species; P, planted species; N, new record for Harrison County, Texas. Wetland classifications (Lichvar, 2013) are listed as follows: OBL, obligate wetland; FACW, facultative wetland; FAC, facultative; FACU, facultative upland; UP, obligate upland]

\begin{tabular}{|c|c|c|}
\hline Family & Scientific name and authority [wetland classification] & Common name \\
\hline \multicolumn{3}{|c|}{ Dicots-Continued } \\
\hline & $\begin{array}{l}\text { Aiton }[\mathrm{N}, \mathrm{FAC}] \\
\text { ria Aiton }[\mathrm{N}, \mathrm{FAC}]\end{array}$ & $\begin{array}{l}\text { American holly } \\
\text { yaupon }\end{array}$ \\
\hline
\end{tabular}

Araliaceae

Aralia spinosa L. [N, FAC]

Hydrocotyle umbellata L. [N, OBL]

Asteraceae
Achillea millefolium L. [N, FACU]

Ambrosia artemisiifolia $\mathrm{L}$. [N, FACU]

Ambrosia psilostachya DC. [N, FAC]

Ambrosia trifida L. [N, FAC]

Arnoglossum plantagineum Raf. [N, FACU]

Baccharis halimifolia L. [FAC]

Bidens aristosa (Michx.) Britton [N, FACW]

Bidens discoidea (Torr. \& A. Gray) Britton [N, FACW]

Bidens laevis (L.) Britton, Sterns \& Poggenb. [N, OBL]

Boltonia diffusa Elliot [FAC]

Carduus nutans L. [N, UPL]

Chrysopsis gossypina ssp. gossypina (Michx.) Elliot [N, UPL]

Cirsium horridulum Michx. [FAC]

Cirsium texanum Buckley [N, UPL]

Conoclinium coelestinum (L) DC [N, FAC]

Conyza canadensis (L.) Cronquist [N, FACU]

Coreopsis lanceolata $\mathrm{L}$. [N, UPL]

Coreopsis tinctoria Nutt. [FAC]

Echinacea pallida (Nutt.) Nutt. [N, UPL]

Eclipta prostrata (L.) L. [N, FACW]

Elephantopus carolinianus Raeusch. [N, FACU]

Elephantopus tomentosus L. [N, UPL]

Erechtites hieraciifolius (L.) Raf. ex DC. [N, FAC]

Erigeron philadelphicus L. [N, FAC]

Erigeron strigosus Muhl. ex Willd. [FAC]

Eupatorium capillifolium (Lam.) Small [N, FACU]

Eupatorium perfoliatum L. [N, FACW]

Eupatorium rotundifolium L. [N, FAC]

Eupatorium semiserratum DC. [N, FACW]

Eupatorium serotinum Michx. [N, FAC]

Euthamia gymnospermoides Greene [N, FAC]

Euthamia leptocephala (Torr. \& A. Gray) Greene ex Porter \& Britton [N, FACW]

Gaillardia pulchella Foug. [N, P, UPL]

Gamochaeta purpurea (L.) Cabrera [N, UPL]

Helenium amarum (Raf.) H. Rock [N, FACU]

Helenium flexuosum Raf. [FACW]

Helianthus angustifolius L. [FACW]

Helianthus grosseserratus M. Martens [N, FAC]

Helianthus hirsutus Raf. [UPL] devil's walkingstick

manyflower marshpennywort

common yarrow

annual ragweed

Cuman ragweed

great ragweed

groovestem Indian plantain

eastern baccharis

bearded beggarticks

small beggarticks

smooth beggarticks

smallhead doll's daisy

nodding plumeless thistle

soft goldenaster

yellow thistle

Texas thistle

blue mistflower

Canadian horseweed

lanceleaf tickseed

golden tickseed

pale purple coneflower

false daisy

Carolina elephantsfoot

devil's grandmother

fireweed

Philadelphia fleabane

prairie fleabane

dogfennel

common boneset

roundleaf thoroughwort

smallflower thoroughwort

lateflowering thoroughwort

Texas goldentop

bushy goldentop

firewheel

spoonleaf purple everlasting

yellowdicks

purplehead sneezeweed

swamp sunflower

sawtooth sunflower

hairy sunflower 
Table 1. Comprehensive list of vascular plants identified at Caddo Lake National Wildlife Refuge, Texas, March 2011-March 2012. -Continued

[E, exotic species; P, planted species; N, new record for Harrison County, Texas. Wetland classifications (Lichvar, 2013) are listed as follows: OBL, obligate wetland; FACW, facultative wetland; FAC, facultative; FACU, facultative upland; UP, obligate upland]

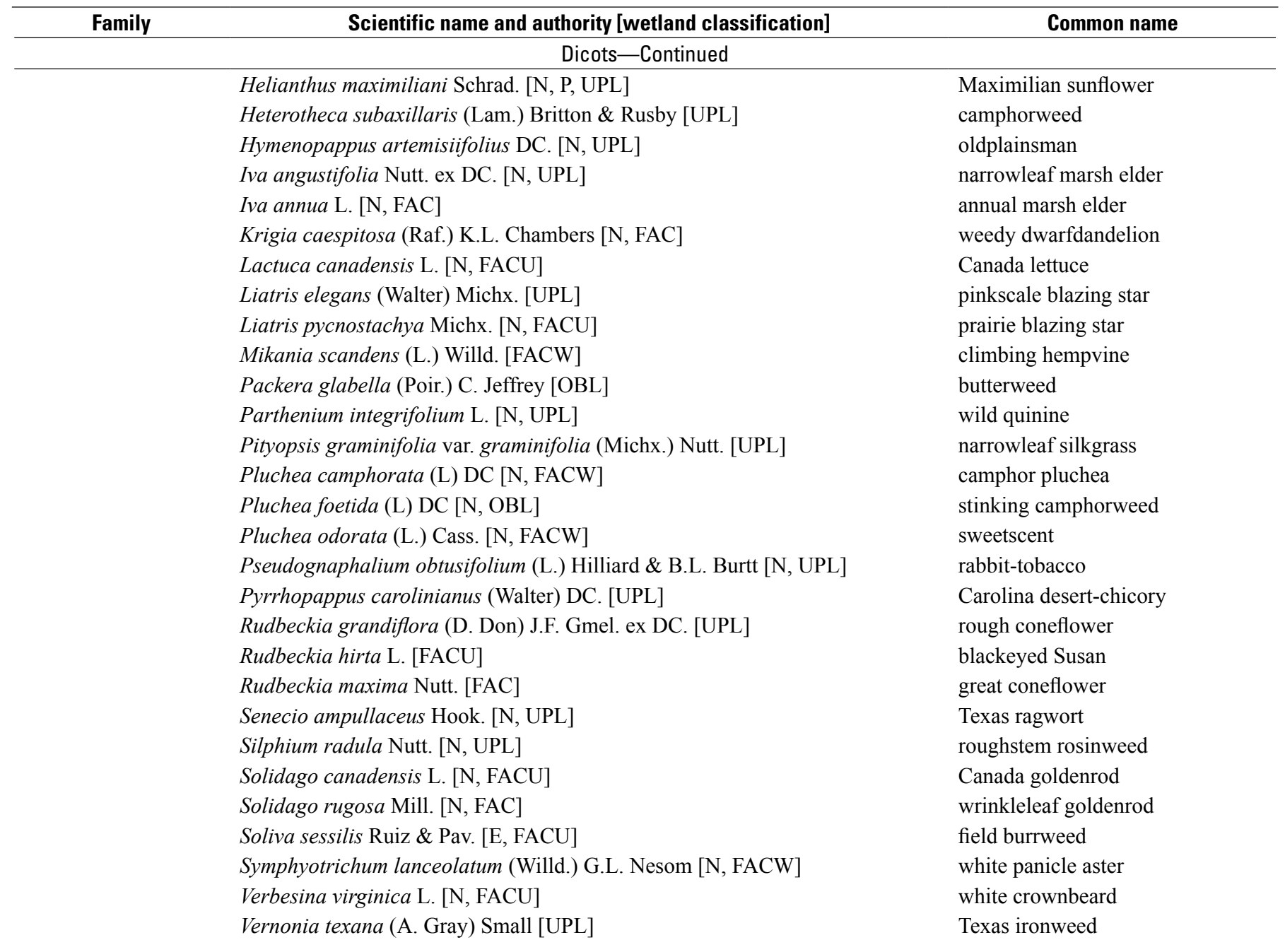

Berberidaceae

Nandina domestica Thunb. [E, N, UPL]

sacred bamboo

Podophyllum peltatum L. [FACU]

mayapple

Betulaceae

Carpinus caroliniana Walter [N, FAC]

Ostrya virginiana (Mill.) K. Koch [N, FACU]

Bignoniaceae

Bignonia capreolata L. [N, FAC]

Campsis radicans (L.) Seem. ex Bureau [N, FAC]

Boraginaceae
Heliotropium curassavicum L. [N, OBL]

Heliotropium indicum L. [FAC]

Myosotis discolor Pers. [N, FACU]
American hornbeam

hophornbeam

crossvine

trumpet creeper

salt heliotrope

Indian heliotrope

changing forget-me-not 
Table 1. Comprehensive list of vascular plants identified at Caddo Lake National Wildlife Refuge, Texas, March 2011-March 2012. -Continued

[E, exotic species; P, planted species; N, new record for Harrison County, Texas. Wetland classifications (Lichvar, 2013) are listed as follows: OBL, obligate wetland; FACW, facultative wetland; FAC, facultative; FACU, facultative upland; UP, obligate upland]

\begin{tabular}{ccc}
\hline Family & Scientific name and authority [wetland classification] & Common name \\
\hline Dicots_Continued &
\end{tabular}

Brassicaceae

Cardamine bulbosa (Schreb. ex Muhl.) Britton, Sterns \& Poggenb. [N, OBL]

Cardamine hirsuta L. [E, N, FACU]

Lepidium virginicum $\mathrm{L}$. [N, UPL]

Rorippa sessiliflora (Nutt.) Hitchc. [N, OBL]

Campanulaceae

Lobelia appendiculata A. DC. [FAC]

Triodanis perfoliata ssp. biflora (Ruiz \& Pav.) Lammers [UPL]

Triodanis perfoliata ssp. perfoliata (L.) Nieuwl. [FACU]

Cannabaceae

Celtis laevigata Willd. [N, FACW]

Caprifoliaceae

Lonicera japonica Thunb. [E, N, FAC]

Caryophyllaceae

Cerastium glomeratum Thuill. [N, FACU]

Stellaria media (L.) Vill. [E, N, FACU]

Celastraceae

Euonymus americanus L. [N, FAC]

Cistaceae

Lechea mucronata Raf. [UPL]

Lechea tenuifolia Michx. [UPL]

Convolvulaceae

Cuscuta indecora Choisy [N, UPL]

Dichondra carolinensis Michx. [FAC]

Ipomoea hederacea Jacq. [N, FAC]

Ipomoea lacunosa L. [N, FAC]

Cornaceae

Cornus drummondii C.A. Mey. [N, FAC]

Cornus florida L. [FACU]

Cucurbitaceae

Melothria pendula L. [N, FACW]

Droseraceae

Drosera brevifolia Pursh [N, OBL]

Ebenaceae bulbous bittercress

hairy bittercress

Virginia pepperweed

stalkless yellowcress

pale lobelia

small Venus' looking-glass

clasping Venus' looking-glass

sugarberry

Japanese honeysuckle

sticky chickweed

common chickweed

bursting-heart

hairy pinweed

narrowleaf pinweed

bigseed alfalfa dodder Carolina ponysfoot ivyleaf morning-glory whitestar

roughleaf dogwood flowering dogwood

Guadeloupe cucumber

dwarf sundew

common persimmon 
Table 1. Comprehensive list of vascular plants identified at Caddo Lake National Wildlife Refuge, Texas, March 2011-March 2012. -Continued

[E, exotic species; P, planted species; N, new record for Harrison County, Texas. Wetland classifications (Lichvar, 2013) are listed as follows: OBL, obligate wetland; FACW, facultative wetland; FAC, facultative; FACU, facultative upland; UP, obligate upland]

\begin{tabular}{lcc}
\hline \multicolumn{1}{c}{ Family } & Scientific name and authority [wetland classification] & Common name \\
\hline Ericaceae & Dicots-Continued & farkleberry
\end{tabular}

Euphorbiaceae

\author{
Acalypha gracilens A. Gray [N, FAC] \\ Acalypha virginica $\mathrm{L}$. [N, FACU] \\ Cnidoscolus texanus (Müll. Arg.) Small [N, UPL] \\ Croton capitatus Michx. [N, UPL] \\ Croton glandulosus L. [N, UPL] \\ Croton michauxii G.L. Webster [N, UPL] \\ Croton monanthogynus Michx. [N, UPL] \\ Euphorbia corollata L. [N, UPL] \\ Euphorbia nutans Lag. [E, N, FACU] \\ Euphorbia spathulata Lam. [N, FACU] \\ Triadica sebifera (L.) Small [E, N, FAC]
}

Fabaceae

Albizia julibrissin Durazz. [E, N, UPL]

Baptisia leucophaea [N, UPL]

Baptisia nuttalliana Small [N, UPL]

Centrosema virginianum (L.) Benth. [UPL]

Cercis canadensis L. [N, FACU]

Chamaecrista fasciculata (Michx.) Greene var. fasciculata [FACU]

Clitoria mariana L. [FACU]

Crotalaria sagittalis L. [UPL]

Desmanthus illinoensis (Michx.) MacMill. ex B.L. Rob. \& Fernald [N, P, FAC]

Desmodium ciliare (Muhl. ex Willd.) DC. [UPL]

Desmodium glabellum (Michx.) DC. [N, UPL]

Desmodium marilandicum (L.) DC. [UPL]

Desmodium paniculatum (L.) DC. [N, FACU]

Desmodium sessilifolium (Torr.) Torr. \& A. Gray [N, UPL]

Erythrina herbacea L. [N, UPL]

Galactia volubilis (L.) Britton [N, FACU]

Gleditsia aquatica Marshall [N, OBL]

Gleditsia triacanthos L. [N, FAC]

Kummerowia striata (Thunb.) Schindl. [E, FACU]

Lespedeza cuneata (Dum. Cours.) G. Don [E, FACU]

Lespedeza repens (L.) W.P.C. Barton [UPL]

Lespedeza virginica (L.) Britton [UPL]

Medicago arabica (L.) Huds. [E, N, UPL]

Medicago polymorpha L. [E, N, FACU]

Melilotus indicus (L.) All. [E, N, FACU]

Mimosa hystricina (Small ex Britton \& Rose) B.L. Turner [N, UPL]

Mimosa strigillosa Torr. \& A. Gray [N, FAC]

Senna marilandica (L.) Link [N, FAC]

Sesbania vesicaria (Jacq.) Elliott [FAC]

Strophostyles helvola (L.) Elliott [N, FAC] slender threeseed mercury

Virginia threeseed mercury

Texas bullnettle

hogwort

vente conmigo

Michaux's croton

prairie tea

flowering spurge

eyebane

warty spurge

Chinese tallow

silktree

longbract wild indigo

Nuttall's wild indigo

spurred butterfly pea

eastern redbud

partridge pea

Atlantic pigeonwings

arrowhead rattlebox

Illinois bundleflower

hairy small-leaf ticktrefoil

Dillenius' ticktrefoil

smooth small-leaf ticktrefoil

panicledleaf ticktrefoil

sessileleaf ticktrefoil

redcardinal

downy milkpea

water locust

honeylocust

Japanese clover

sericea lespedeza

creeping lespedeza

slender lespedeza

spotted medick

burclover

annual yellow sweetclover

porcupine mimosa

powderpuff

Maryland senna

bagpod

amberique-bean 
Table 1. Comprehensive list of vascular plants identified at Caddo Lake National Wildlife Refuge, Texas, March 2011-March 2012. -Continued

[E, exotic species; P, planted species; N, new record for Harrison County, Texas. Wetland classifications (Lichvar, 2013) are listed as follows: OBL, obligate wetland; FACW, facultative wetland; FAC, facultative; FACU, facultative upland; UP, obligate upland]

\begin{tabular}{|c|c|c|}
\hline Family & Scientific name and authority [wetland classification] & Common name \\
\hline \multicolumn{3}{|c|}{ Dicots-Continued } \\
\hline & Strophostyles leiosperma (Torr. \& A. Gray) Piper [UPL] & slickseed fuzzybean \\
\hline & Strophostyles umbellata (Muhl. ex Willd.) Britton [FAC] & pink fuzzybean \\
\hline & Stylosanthes biflora (L.) Britton, Sterns \& Poggenb. [UPL] & sidebeak pencilflower \\
\hline & Tephrosia onobrychoides Nutt. [UPL] & multibloom hoarypea \\
\hline & Trifolium campestre Schreb. [E, N, UPL] & field clover \\
\hline & Trifolium pratense L. [E, N, FACU] & red clover \\
\hline & Trifolium repens L. [E, N, FACU] & white clover \\
\hline & Vicia minutiflora D. Dietr. [N, FAC] & pygmyflower vetch \\
\hline & Vicia sativa $\mathrm{L} .[\mathrm{E}, \mathrm{N}, \mathrm{FACU}]$ & garden vetch \\
\hline & Vicia villosa Roth [E, N, UPL] & winter vetch \\
\hline
\end{tabular}

Fagaceae

Quercus alba L. [N, FACU]

Quercus falcata Michx. [N, FACU]

Quercus lyrata Walter [N, OBL]

Quercus marilandica Münchh. [N, UPL]

Quercus nigra L. [N, FAC]

Quercus phellos L. [N, FACW]

Quercus stellata Wangenh. [N, UPL]

Quercus virginiana Mill. [N, P, FACU]

Sabatia campestris Nutt. [N, FACU]

Geraniaceae

Geranium carolinianum L. [N, UPL]

Geranium dissectum L. [N, UPL]

Hydrocharitaceae

Hydrilla verticillata (L. f.) Royle [E, N, OBL]

Hydroleaceae

Hydrolea ovata Nutt. ex Choisy [OBL]

Hydrolea uniflora Raf. [OBL]

Hypericaceae
Hypericum drummondii (Grev. \& Hook.) Torr. \& A. Gray [N, FACU]

Hypericum fasciculatum Lam. [N, FACW]

Hypericum gymnanthum Engelm. \& A. Gray [N, FACW]

Hypericum hypericoides (L.) Crantz [FAC]

Hypericum punctatum Lam. [N, FAC]

Triadenum walteri (J.F. Gmel.) Gleason [N, OBL] white oak

southern red oak

overcup oak

blackjack oak

water oak

willow oak

post oak

live oak

Texas star

Carolina geranium cutleaf geranium

waterthyme

ovate false fiddleleaf oneflower false fiddleleaf

nits and lice peelbark St. Johnswort claspingleaf St. Johnswort St. Andrew's cross spotted St. Johnswort greater marsh St. Johnswort 
Table 1. Comprehensive list of vascular plants identified at Caddo Lake National Wildlife Refuge, Texas, March 2011-March 2012. -Continued

[E, exotic species; P, planted species; N, new record for Harrison County, Texas. Wetland classifications (Lichvar, 2013) are listed as follows: OBL, obligate wetland; FACW, facultative wetland; FAC, facultative; FACU, facultative upland; UP, obligate upland]

\begin{tabular}{lll}
\hline \multicolumn{1}{c}{ Family } & \multicolumn{1}{c}{ Scientific name and authority [wetland classification] } & \multicolumn{1}{c}{ Common name } \\
\hline Juglandaceae & \multicolumn{1}{c}{ Dicots-Continued } & water hickory \\
& Carya aquatica $(\mathrm{F}$. Michx.) Elliott $[\mathrm{N}, \mathrm{OBL}]$ & bitternut hickory \\
& Carya cordiformis $($ Wangenh.) K. Koch [FAC] & pecan \\
& Carya illinoinensis (Wangenh.) K. Koch $[\mathrm{N}, \mathrm{FACU}]$ & black walnut \\
& Juglans nigra L. $[\mathrm{N}, \mathrm{P}, \mathrm{UPL}]$ &
\end{tabular}

Lamiaceae

\author{
Callicarpa americana L. [N, FACU] \\ Lamium amplexicaule L. [E, N, UPL] \\ Lycopus rubellus Moench [OBL] \\ Monarda fistulosa L. [FACU] \\ Perilla frutescens (L.) Britton [E, N, UPL] \\ Physostegia intermedia (Nutt.) Engelm. \& A. Gray [N, FACW] \\ Prunella vulgaris L. [FAC] \\ Pycnanthemum tenuifolium Schrad. [N, FACW] \\ Salvia lyrata L. [FACU] \\ Scutellaria ovata Hill [N, UPL] \\ Scutellaria parvula Michx. [N, FACU] \\ Stachys tenuifolia Willd. [N, FACW] \\ Teucrium canadense L. [FACW]
}

Lauraceae

Sassafras albidum (Nutt.) Nees [N, FACU]

Linaceae

Linum medium var. texanum (Planch.) Fernald [UPL]

Lythraceae

Ammannia coccinea Rottb. [N, OBL]

Lythrum alatum var. lanceolatum (Elliott) Torr. \& A. Gray ex Rothr. [OBL]

Rotala ramosior (L.) Koehne [N, OBL]

Malvaceae

Hibiscus laevis All. [OBL]

Hibiscus moscheutos ssp. lasiocarpos (Cav.) O.J. Blanch. [OBL]

Sida rhombifolia L. [N, FACU]

Melastomataceae

Rhexia mariana L. [FACW]

Meliaceae

Melia azedarach L. [E, N, UPL]

Menispermaceae

Cocculus carolinus (L.) DC. [N, FAC]

Molluginaceae
Chinaberry tree

American beautyberry

henbit deadnettle

taperleaf water horehound

wild bergamot

beefsteak plant

slender false dragonhead

common selfheal

narrowleaf mountainmint

lyreleaf sage

heartleaf skullcap

small skullcap

smooth hedgenettle

Canada germander

sassafras

stiff yellow flax

valley redstem

winged lythrum

lowland rotala

halberdleaf rosemallow

rosemallow

Cuban jute

Maryland meadowbeauty

Carolina coralbead

green carpetweed 
Table 1. Comprehensive list of vascular plants identified at Caddo Lake National Wildlife Refuge, Texas, March 2011-March 2012. -Continued

[E, exotic species; P, planted species; N, new record for Harrison County, Texas. Wetland classifications (Lichvar, 2013) are listed as follows: OBL, obligate wetland; FACW, facultative wetland; FAC, facultative; FACU, facultative upland; UP, obligate upland]

\begin{tabular}{ccc}
\hline Family & Scientific name and authority [wetland classification] & Common name \\
\hline Dicots-Continued & \\
\hline
\end{tabular}

Montiaceae

Moraceae

Maclura pomifera (Raf.) C.K. Schneid. [N, FACU]

Morus rubra L. [N, FACU]

Myricaceae

Morella cerifera (L.) Small [FAC]

Nelumbonaceae

Nelumbo lutea Willd. [N, OBL]

Nymphaeaceae

Nuphar lutea (L.) Sm. [OBL]

Nyssaceae

Nyssa sylvatica Marshall [FAC]

Oleaceae

Chionanthus virginicus L. [FACU]

Forestiera acuminata (Michx.) Poir. [N, OBL]

Fraxinus americana $\mathrm{L}$. [N, FACU]

Fraxinus pennsylvanica Marsh. [FACW]

Ligustrum sinense Lour. [E, N, UPL]

Onagraceae

Oenothera filiformis (Small) W.L. Wagner \& Hoch [N, UPL]

Ludwigia alternifolia $\mathrm{L}$. [N, OBL]

Ludwigia decurrens (DC.) Walter [N, OBL]

Ludwigia glandulosa Walter [N, OBL]

Ludwigia leptocarpa (Nutt.) H. Hara [N, OBL]

Ludwigia linearis Walter [N, OBL]

Ludwigia palustris (L.) Elliott [N, OBL]

Ludwigia peploides (Kunth) P.H. Raven [N, OBL]

Oenothera biennis L. [N, FACU]

Oenothera laciniata Hill [N, FACU]

Oenothera linifolia Nutt. [N, UPL]

Oenothera speciosa Nutt. [E, N, UPL]

Orobanchaceae

Agalinis purpurea (L.) Pennell [N, FACW]

Castilleja indivisa Engelm. [N, P, FAC]

Parentucellia viscosa (L.) Caruel [E, FAC]

Oxalidaceae

Oxalis dillenii Jacq. [N, FACU]

Oxalis stricta L. [N, UPL]

Oxalis violacea L. [N, UPL] osage orange

red mulberry

wax myrtle

American lotus

yellow pond-lily

blackgum

white fringetree

eastern swampprivet

white ash

green ash

Chinese privet

longflower beeblossom seedbox

wingleaf primrose-willow cylindricfruit primrose-willow anglestem primrose-willow narrowleaf primrose-willow marsh seedbox

floating primrose-willow common evening primrose cutleaf evening primrose threadleaf evening primrose pinkladies

purple false foxglove entireleaf Indian paintbrush yellow glandweed

slender yellow woodsorrel common yellow oxalis violet woodsorrel 
Table 1. Comprehensive list of vascular plants identified at Caddo Lake National Wildlife Refuge, Texas, March 2011-March 2012. -Continued

[E, exotic species; P, planted species; N, new record for Harrison County, Texas. Wetland classifications (Lichvar, 2013) are listed as follows: OBL, obligate wetland; FACW, facultative wetland; FAC, facultative; FACU, facultative upland; UP, obligate upland]

\begin{tabular}{ccc}
\hline Family & Scientific name and authority [wetland classification] & Common name \\
\hline Dicots-Continued &
\end{tabular}

Passifloraceae

Passiflora incarnata L. [N, UPL]

Passiflora lutea L. [N, UPL]

Penthoraceae

Penthorum sedoides L. [OBL]

Phytolaccaceae

Phytolacca americana L. [N, FACU]

Plantaginaceae

Callitriche heterophylla Pursh [OBL]

Callitriche terrestris Raf. [N, FACW]

Mecardonia acuminata (Walter) Small [N, FACW]

Nuttallanthus canadensis (L.) D.A. Sutton [N, UPL]

Penstemon digitalis Nutt. ex Sims [FAC]

Plantago aristata Michx. [UPL]

Plantago virginica L. [FACU]

Veronica arvensis L. [E, N, UPL]

Veronica peregrina L. [N, FAC]

Platanaceae

Platanus occidentalis L. [N, FACW]

Polemoniaceae

Phlox pilosa ssp. pilosa L. [N, FACU]

Polygalaceae

Polygala mariana Mill. [N, FACW]

Polygala verticillata L. [N, UPL]

Polygonaceae

Brunnichia ovata (Walter) Shinners [FACW]

Persicaria glabra (Willd.) M. Gomez [N, OBL]

Persicaria hydropiper L. (Opiz) [E, N, OBL]

Persicaria hydropiperoides (Michx.) Small [FACW]

Persicaria maculosa Gray [E, N, FACW]

Persicaria punctata (Elliott) Small [N, OBL]

Persicaria setacea (Baldw.) Small [N, OBL]

Rumex hastatulus Baldwin [FACU]

Rumex crispus L. [E, N, FAC]

Primulaceae purple passionflower

yellow passionflower

ditch stonecrop

American pokeweed

twoheaded water-starwort terrestrial water-starwort

axilflower

Canada toadflax

talus slope penstemon

largebracted plantain

Virginia plantain

corn speedwell

neckweed

sycamore

downy phlox

Maryland milkwort

whorled milkwort

American buckwheat vine denseflower knotweed marshpepper knotweed swamp smartweed spotted ladysthumb dotted smartweed bog smartweed heartwing sorrel curly dock

scarlet pimpernel

American featherfoil 
Table 1. Comprehensive list of vascular plants identified at Caddo Lake National Wildlife Refuge, Texas, March 2011-March 2012. -Continued

[E, exotic species; P, planted species; N, new record for Harrison County, Texas. Wetland classifications (Lichvar, 2013) are listed as follows: OBL, obligate wetland; FACW, facultative wetland; FAC, facultative; FACU, facultative upland; UP, obligate upland]

\begin{tabular}{lll}
\hline \multicolumn{1}{c}{ Family } & \multicolumn{1}{c}{ Scientific name and authority [wetland classification] } & Common name \\
\hline Ranunculaceae & \multicolumn{1}{c}{ Dicots_Continued } & Carolina anemone \\
& Anemone caroliniana Walter [N, UPL] & swamp leather flower \\
& Clematis crispa L. [N, FACW] & Carolina larkspur \\
& Delphinium carolinianum Walter [N, UPL] & low spearwort
\end{tabular}

Rhamnaceae

Berchemia scandens (Hill) K. Koch [FAC]

Rhamnus caroliniana Walter [FACU]

Rosaceae

Rubiaceae

Cephalanthus occidentalis L. [N, OBL]

Diodella teres (Walter) Small [N, FACU]

Diodia virginiana $\mathrm{L}$. [N, FACW]

Galium aparine L. [N, FACU]

Galium circaezans Michx. [N, FACU]

Galium obtusum Bigelow [N, FACW]

Galium tinctorium L. [N, FACW]

Houstonia micrantha (Shinners) Terrell [N, UPL]

Houstonia pusilla Schoepf [N, FACU]

Houstonia rosea (Raf.) Terrell [N, UPL]

Mitchella repens L. [FACU]

Sherardia arvensis L. [E, N, UPL]

Spermacoce glabra Michx. [N, FACW]

Stenaria nigricans (Lam.) Terrell [UPL]
Alabama supplejack

Carolina buckthorn

blueberry hawthorn cockspur hawthorn parsley hawthorn littlehip hawthorn green hawthorn Indian strawberry white avens sulphur cinquefoil Chickasaw plum black cherry hog plum Callery pear Carolina rose sawtooth blackberry northern dewberry southern dewberry

common buttonbush poorjoe Virginia buttonweed catchweed bedstraw licorice bedstraw bluntleaf bedstraw stiff marsh bedstraw southern bluet tiny bluet rose bluet partridgeberry blue fieldmadder smooth false buttonweed diamondflowers

Rutaceae 
Table 1. Comprehensive list of vascular plants identified at Caddo Lake National Wildlife Refuge, Texas, March 2011-March 2012. -Continued

[E, exotic species; P, planted species; N, new record for Harrison County, Texas. Wetland classifications (Lichvar, 2013) are listed as follows: OBL, obligate wetland; FACW, facultative wetland; FAC, facultative; FACU, facultative upland; UP, obligate upland]

\begin{tabular}{ccc}
\hline Family & Scientific name and authority [wetland classification] & Common name \\
\hline & Dicots-Continued & \\
\hline
\end{tabular}

Salicaceae

Populus deltoides W. Bartram ex Marshall [N, FAC]

Populus nigra L. [E, P, N, UPL]

Salix nigra Marshall [N, OBL]

Santalaceae

Phoradendron tomentosum (DC.) Engelm. ex A. Gray [N, UPL]

Sapindaceae

Acer saccharum var. saccharum Marsh. [N, UPL]

Acer negundo L. [N, FAC]

Acer rubrum L. [N, FAC]

Aesculus pavia L. [FACU]

Sapotaceae

Sideroxylon lanuginosum Michx. [FACU]

Saururaceae

Saururus cernuus L. [N, OBL]

Scrophulariaceae

Verbascum thapsus L. [E, N, FACU]

Solanaceae

Solanum carolinense L. [N, FACU]

Styracaceae

Styrax americanus Lam. [FACW]

Symplocaceae

Symplocos tinctoria (L.) L'Hér. [FAC]

Tetrachondraceae

Polypremum procumbens L. [N, FACU]

Ulmaceae

Planera aquatica J.F. Gmel. [OBL]

Ulmus alata Michx. [N, FACU]

Ulmus americana $\mathrm{L}$. [N, FAC]

Urticaceae

Boehmeria cylindrica (L.) Sw. [FACW]

Pilea pumila (L.) A. Gray [N, FAC]

Urtica chamaedryoides Pursh [N, FAC]

Valerianaceae eastern cottonwood

Lombardy's poplar

black willow

Christmas mistletoe

southern sugar maple

boxelder

red maple

red buckeye

gum bully

lizard's tail

common mullein

Carolina horsenettle

American snowbell

common sweetleaf

juniper-leaf

planertree

winged elm

American elm

smallspike false nettle

Canadian clearweed

heartleaf nettle

beaked cornsalad 
Table 1. Comprehensive list of vascular plants identified at Caddo Lake National Wildlife Refuge, Texas, March 2011-March 2012. -Continued

[E, exotic species; P, planted species; N, new record for Harrison County, Texas. Wetland classifications (Lichvar, 2013) are listed as follows: OBL, obligate wetland; FACW, facultative wetland; FAC, facultative; FACU, facultative upland; UP, obligate upland]

\begin{tabular}{|c|c|c|}
\hline Family & Scientific name and authority [wetland classification] & Common name \\
\hline \multicolumn{3}{|c|}{ Dicots-Continued } \\
\hline \multicolumn{3}{|l|}{ Verbenaceae } \\
\hline & Phyla lanceolata (Michx.) Greene [N, OBL] & lanceleaf fogfruit \\
\hline & Verbena brasiliensis Vell. [E, N, UPL] & Brazilian vervain \\
\hline & Verbena halei Small [N, UPL] & Texas vervain \\
\hline & Verbena urticifolia $\mathrm{L} .[\mathrm{N}, \mathrm{FAC}]$ & white vervain \\
\hline \multicolumn{3}{|l|}{ Violaceae } \\
\hline & Viola bicolor Pursh [N, FAC] & field pansy \\
\hline & Viola sororia Willd. [FAC] & common blue violet \\
\hline \multicolumn{3}{|l|}{ Vitaceae } \\
\hline & Ampelopsis arborea (L.) Koehne [N, FAC] & peppervine \\
\hline & Vitis cinerea (Engelm.) Engelm. ex Millard [N, FAC] & graybark grape \\
\hline & Vitis riparia Michx. [N, FACW] & riverbank grape \\
\hline & Vitis rotundifolia Michx. [N, FACW] & muscadine \\
\hline & Vitis vulpina $\mathrm{L} .[\mathrm{N}, \mathrm{FAC}]$ & frost grape \\
\hline
\end{tabular}


Table 2. List of nonnative plant species occurring at Caddo Lake National Wildlife Refuge, Texas, March $2011-M a r c h ~ 2012$.

\begin{tabular}{|c|c|c|}
\hline Scientific name & Common name & Family \\
\hline Albizia julibrissin & silktree & Fabaceae \\
\hline Alternanthera philoxeroides & alligatorweed & Amaranthaceae \\
\hline Bothriochloa ischaemum var. songarica & King's Ranch bluestem & Poaceae \\
\hline Briza minor & little quakinggrass & Poaceae \\
\hline Cardamine hirsuta & hairy bittercress & Brassicaceae \\
\hline Cerastium glomeratum & sticky chickweed & Caryophyllaceae \\
\hline Commelina communis & Asiatic dayflower & Commelinaceae \\
\hline Cynodon dactylon & Bermudagrass & Poaceae \\
\hline Digitaria ischaemum & smooth crabgrass & Poaceae \\
\hline Eichhornia crassipes & common water hyacinth & Pontederiaceae \\
\hline Eleusine indica & goosegrass & Poaceae \\
\hline Euphorbia nutans & eyebane & Euphorbiaceae \\
\hline Hydrilla verticillata & waterthyme & Hydrocharitaceae \\
\hline Iris albicans & cemetery iris & Iridaceae \\
\hline Kummerowia striata & Japanese clover & Fabaceae \\
\hline Lamium amplexicaule & henbit deadnettle & Lamiaceae \\
\hline Lespedeza cuneata & sericea lespedeza & Fabaceae \\
\hline Melia azedarach & Chinaberry tree & Meliaceae \\
\hline Melilotus indicus & annual yellow sweetclover & Fabaceae \\
\hline Mollugo verticillata & green carpetweed & Molluginaceae \\
\hline Nandina domestica & sacred bamboo & Berberidaceae \\
\hline Narcissus jonquilla & jonquil & Amaryllidaceae \\
\hline Oenothera speciosa & pinkladies & Onagraceae \\
\hline Parentucellia viscosa & yellow glandweed & Orobanchaceae \\
\hline Paspalum dilatatum & dallisgrass & Poaceae \\
\hline Paspalum notatum & bahiagrass & Poaceae \\
\hline Paspalum urvillei & Vasey's grass & Poaceae \\
\hline Purilla frutescens & beefsteak plant & Lamiaceae \\
\hline Poa annua & annual bluegrass & Poaceae \\
\hline Persicaria hydropiper & marshpepper knotweed & Polygonaceae \\
\hline Persicaria maculosa & spotted ladysthumb & Polygonaceae \\
\hline Populus nigra & Lombardy's poplar & Salicaceae \\
\hline Potentilla recta & sulphur cinquefoil & Rosaceae \\
\hline
\end{tabular}


Table 2. List of nonnative plant species occurring at Caddo Lake National Wildlife Refuge, Texas, March 2011-March 2012. -Continued

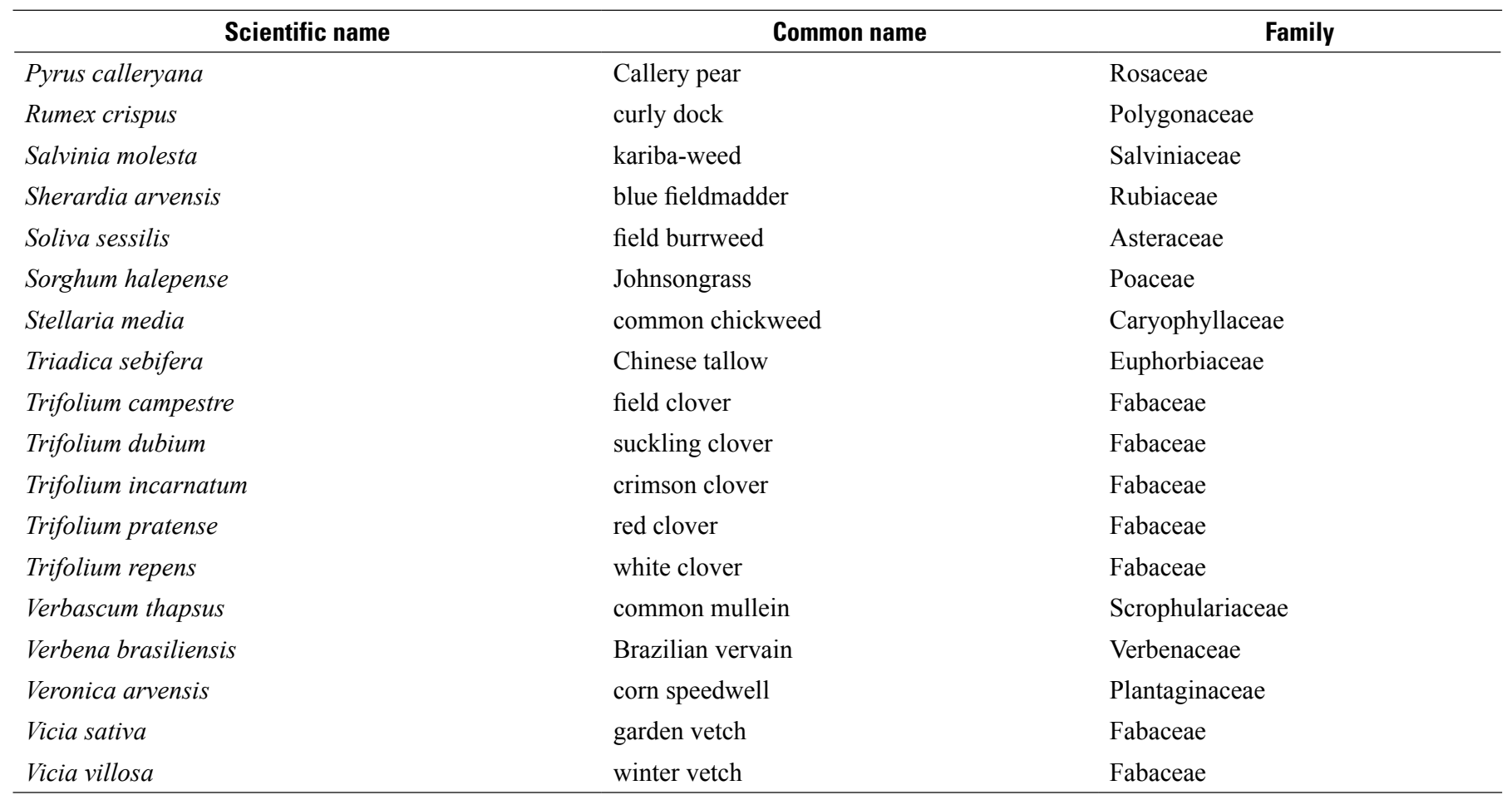


Table 3. List of vascular plant species found at Caddo Lake National Wildlife Refuge, Texas, March 2011-March 2012, with food value for wildlife.

[1, low use; 2 , medium use; 3 , high use. --, no data]

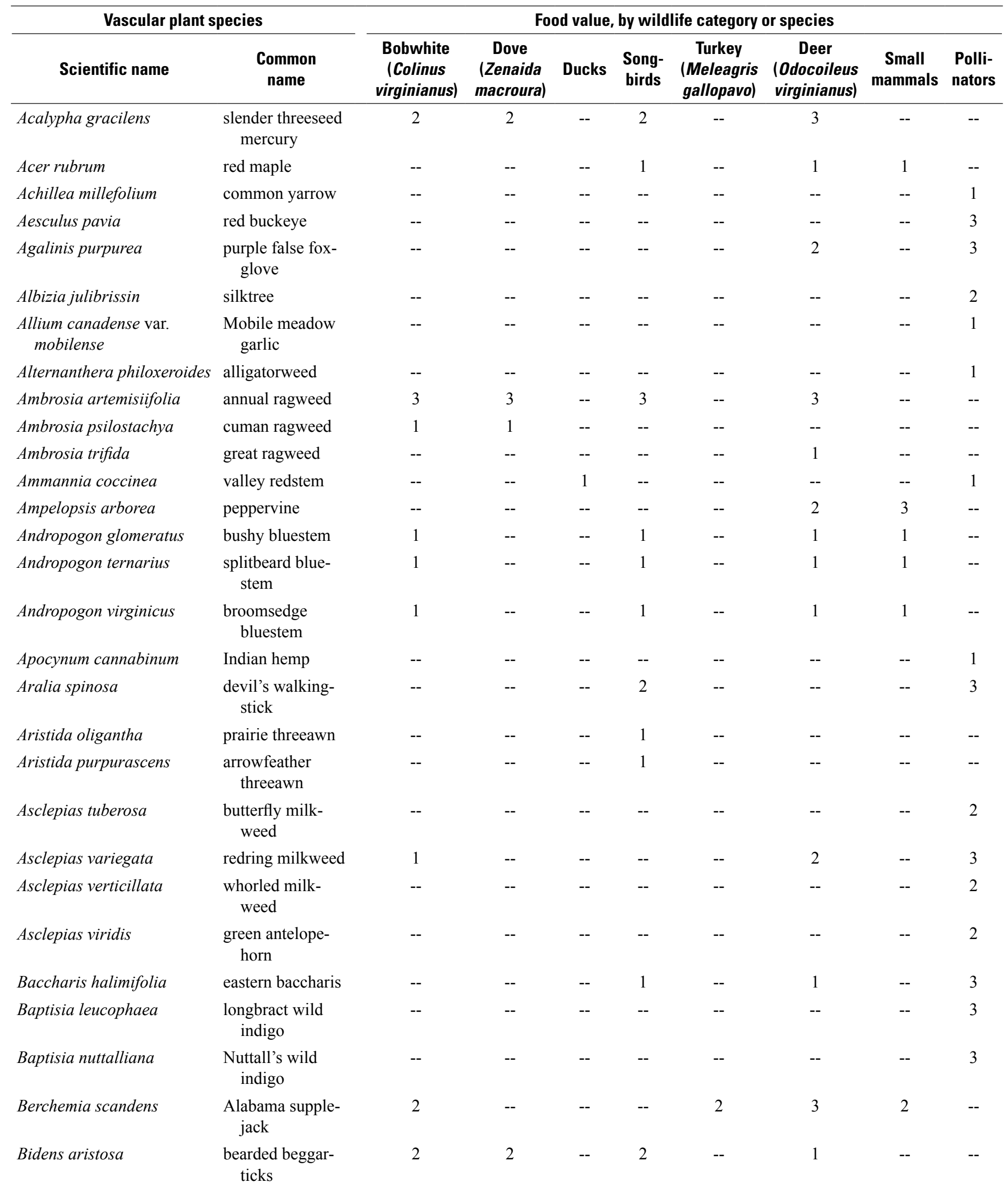


Table 3. List of vascular plant species found at Caddo Lake National Wildlife Refuge, Texas, March 2011-March 2012, with food value for wildlife.-Continued

[1, low use; 2 , medium use; 3 , high use. --, no data]

\begin{tabular}{|c|c|c|c|c|c|c|c|c|c|}
\hline \multicolumn{2}{|c|}{ Vascular plant species } & \multicolumn{8}{|c|}{ Food value, by wildlife category or species } \\
\hline Scientific name & $\begin{array}{l}\text { Common } \\
\text { name }\end{array}$ & $\begin{array}{c}\text { Bobwhite } \\
\text { (Colinus } \\
\text { virginianus) }\end{array}$ & $\begin{array}{c}\text { Dove } \\
\text { (Zenaida } \\
\text { macroura) }\end{array}$ & Ducks & $\begin{array}{l}\text { Song- } \\
\text { birds }\end{array}$ & $\begin{array}{c}\text { Turkey } \\
\text { (Meleagris } \\
\text { gallopavo) }\end{array}$ & $\begin{array}{c}\text { Deer } \\
\text { (Odocoileus } \\
\text { virginianus) }\end{array}$ & $\begin{array}{c}\text { Small } \\
\text { mammals }\end{array}$ & $\begin{array}{l}\text { Polli- } \\
\text { nators }\end{array}$ \\
\hline Bidens discoidea & small beggarticks & 2 & 2 & -- & 2 & -- & 1 & -- & -- \\
\hline Bidens laevis & $\begin{array}{l}\text { smooth beggar- } \\
\text { ticks }\end{array}$ & 2 & 2 & -- & 2 & -- & 1 & -- & 1 \\
\hline Boltonia diffusa & $\begin{array}{l}\text { smallhead doll's } \\
\text { daisy }\end{array}$ & -- & -- & -- & -- & -- & -- & -- & 1 \\
\hline Callicarpa americana & $\begin{array}{l}\text { American beau- } \\
\text { tyberry }\end{array}$ & 2 & -- & -- & 3 & -- & 3 & 2 & 2 \\
\hline Campsis radicans & trumpet creeper & -- & -- & -- & -- & -- & 3 & -- & 2 \\
\hline Carduus nutans & $\begin{array}{l}\text { nodding plume- } \\
\text { less thistle }\end{array}$ & -- & -- & -- & -- & -- & -- & -- & 1 \\
\hline Carex blanda & $\begin{array}{l}\text { eastern woodland } \\
\text { sedge }\end{array}$ & -- & -- & 1 & 3 & 3 & 1 & 3 & -- \\
\hline Carex caroliniana & Carolina sedge & -- & -- & 1 & 3 & 3 & 1 & 3 & -- \\
\hline Carex cephalophora & oval-leaf sedge & -- & -- & 1 & 3 & 3 & 1 & 3 & -- \\
\hline Carex cherokeensis & Cherokee sedge & -- & -- & 1 & 3 & 3 & 1 & 3 & -- \\
\hline Carex complanata & blue sedge & -- & -- & 1 & 3 & 3 & 1 & 3 & -- \\
\hline Carex hyalinolepis & shoreline sedge & -- & -- & 1 & 3 & 3 & 1 & 3 & -- \\
\hline Carex triangularis & eastern fox sedge & -- & -- & 1 & 3 & 3 & 1 & 3 & -- \\
\hline Carex vulpinoidea & fox sedge & -- & -- & 1 & 3 & 3 & 1 & 3 & -- \\
\hline Carya cordiformis & bitternut hickory & -- & -- & -- & -- & -- & 1 & -- & -- \\
\hline Castilleja indivisa & $\begin{array}{l}\text { entireleaf Indian } \\
\text { paintbrush }\end{array}$ & -- & -- & -- & -- & -- & -- & -- & 1 \\
\hline Celtis laevigata & sugarberry & -- & -- & -- & -- & -- & 1 & -- & -- \\
\hline Centrosema virginianum & $\begin{array}{l}\text { spurred butterfly } \\
\text { pea }\end{array}$ & 2 & -- & -- & 1 & -- & -- & -- & 2 \\
\hline Cephalanthus occidentalis & $\begin{array}{l}\text { common button- } \\
\text { bush }\end{array}$ & -- & -- & 3 & 2 & -- & 1 & -- & 2 \\
\hline Cercis canadensis & eastern redbud & -- & -- & -- & -- & -- & -- & -- & 2 \\
\hline $\begin{array}{l}\text { Chamaecrista fasciculata } \\
\text { var. fasciculata }\end{array}$ & partridge pea & 3 & -- & -- & -- & -- & 2 & -- & 2 \\
\hline Chasmanthium latifolium & Indian woodoats & 2 & -- & -- & 2 & -- & 1 & -- & -- \\
\hline Chasmanthium laxum & slender woodoats & 2 & -- & -- & 2 & -- & 1 & -- & -- \\
\hline
\end{tabular}


Table 3. List of vascular plant species found at Caddo Lake National Wildlife Refuge, Texas, March 2011-March 2012, with food value for wildlife.-Continued

[1, low use; 2 , medium use; 3 , high use. --, no data]

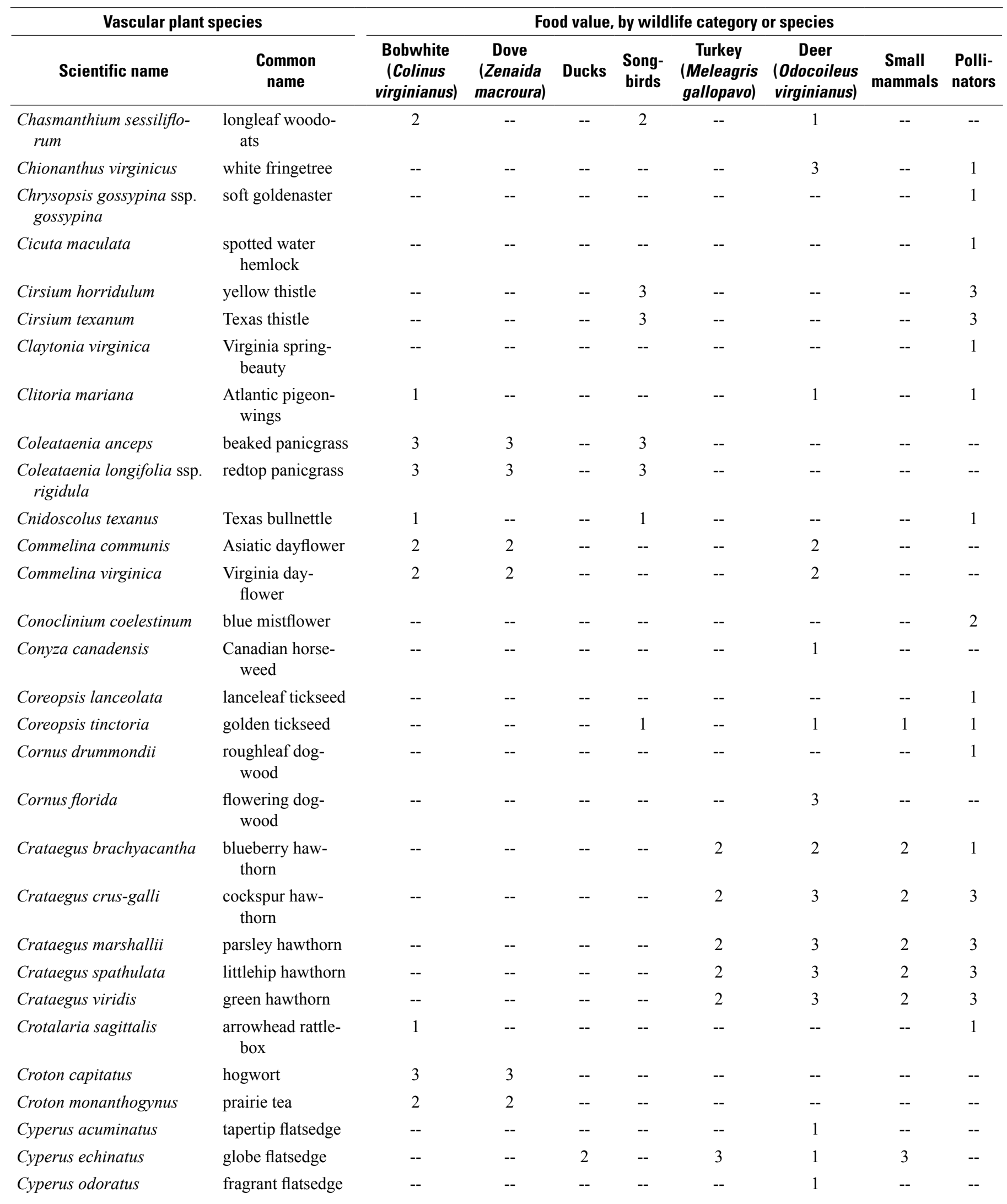


Table 3. List of vascular plant species found at Caddo Lake National Wildlife Refuge, Texas, March 2011-March 2012, with food value for wildlife.-Continued

[1, low use; 2 , medium use; 3 , high use. --, no data]

\begin{tabular}{|c|c|c|c|c|c|c|c|c|c|}
\hline \multicolumn{2}{|c|}{ Vascular plant species } & \multicolumn{8}{|c|}{ Food value, by wildlife category or species } \\
\hline Scientific name & $\begin{array}{l}\text { Common } \\
\text { name }\end{array}$ & $\begin{array}{c}\text { Bobwhite } \\
\text { (Colinus } \\
\text { virginianus) }\end{array}$ & $\begin{array}{c}\text { Dove } \\
\text { (Zenaida } \\
\text { macroura) }\end{array}$ & Ducks & $\begin{array}{l}\text { Song- } \\
\text { birds }\end{array}$ & $\begin{array}{c}\text { Turkey } \\
\text { (Meleagris } \\
\text { gallopavo) }\end{array}$ & $\begin{array}{c}\text { Deer } \\
\text { (Odocoileus } \\
\text { virginianus) }\end{array}$ & $\begin{array}{c}\text { Small } \\
\text { mammals }\end{array}$ & $\begin{array}{l}\text { Polli- } \\
\text { nators }\end{array}$ \\
\hline Cyperus pseudovegetus & marsh flatsedge & -- & -- & -- & -- & -- & 1 & -- & -- \\
\hline Cyperus retrorsus & $\begin{array}{l}\text { pine barren flat- } \\
\text { sedge }\end{array}$ & -- & -- & -- & -- & -- & 1 & -- & -- \\
\hline Cyperus virens & green flatsedge & -- & -- & -- & -- & -- & 1 & -- & -- \\
\hline Daucus carota & $\begin{array}{l}\text { Queen Anne's } \\
\text { lace }\end{array}$ & -- & -- & -- & -- & -- & -- & -- & 1 \\
\hline Desmanthus illinoensis & $\begin{array}{l}\text { Illinois bundle- } \\
\text { flower }\end{array}$ & 2 & 2 & -- & 2 & 2 & -- & -- & -- \\
\hline Desmodium glabellum & $\begin{array}{l}\text { Dillenius' tick- } \\
\text { trefoil }\end{array}$ & 3 & -- & -- & -- & 2 & 3 & -- & -- \\
\hline Desmodium marilandicum & $\begin{array}{l}\text { smooth small-leaf } \\
\text { ticktrefoil }\end{array}$ & 3 & -- & -- & -- & 2 & 3 & -- & -- \\
\hline Desmodium paniculatum & $\begin{array}{r}\text { panicledleaf } \\
\text { ticktrefoil }\end{array}$ & 3 & -- & -- & -- & 2 & 3 & -- & -- \\
\hline Desmodium sessilifolium & $\begin{array}{l}\text { sessileleaf tick- } \\
\text { trefoil }\end{array}$ & 3 & -- & -- & -- & 2 & 3 & -- & -- \\
\hline Dichanthelium aciculare & $\begin{array}{l}\text { needleleaf rosette } \\
\text { grass }\end{array}$ & 3 & 3 & -- & 3 & 2 & 1 & 3 & -- \\
\hline Digitaria ciliaris & $\begin{array}{l}\text { southern crab- } \\
\text { grass }\end{array}$ & 2 & 2 & -- & 2 & 2 & 1 & -- & -- \\
\hline Digitaria ischaemum & smooth crabgrass & 2 & 2 & -- & 2 & 2 & 1 & -- & -- \\
\hline Digitaria sanguinalis & hairy crabgrass & 2 & 2 & -- & 2 & 2 & 1 & -- & -- \\
\hline Digitaria violascens & violet crabgrass & 2 & 2 & -- & 2 & 2 & 1 & -- & -- \\
\hline Diodella teres & poorjoe & 2 & 2 & -- & 2 & 2 & 3 & -- & -- \\
\hline Diodia virginiana & $\begin{array}{l}\text { Virginia button- } \\
\text { weed }\end{array}$ & 2 & 2 & 2 & -- & -- & 3 & 2 & -- \\
\hline Diospyros virginiana & $\begin{array}{l}\text { common persim- } \\
\text { mon }\end{array}$ & -- & -- & -- & -- & -- & -- & -- & 1 \\
\hline Duchesnea indica & Indian strawberry & -- & -- & -- & -- & -- & -- & -- & 1 \\
\hline Echinacea pallida & $\begin{array}{l}\text { pale purple cone- } \\
\text { flower }\end{array}$ & -- & -- & -- & -- & -- & -- & -- & 1 \\
\hline Eclipta prostrata & false daisy & 1 & -- & -- & 1 & -- & -- & -- & -- \\
\hline
\end{tabular}


Table 3. List of vascular plant species found at Caddo Lake National Wildlife Refuge, Texas, March 2011-March 2012, with food value for wildlife.-Continued

[1, low use; 2 , medium use; 3 , high use. --, no data]

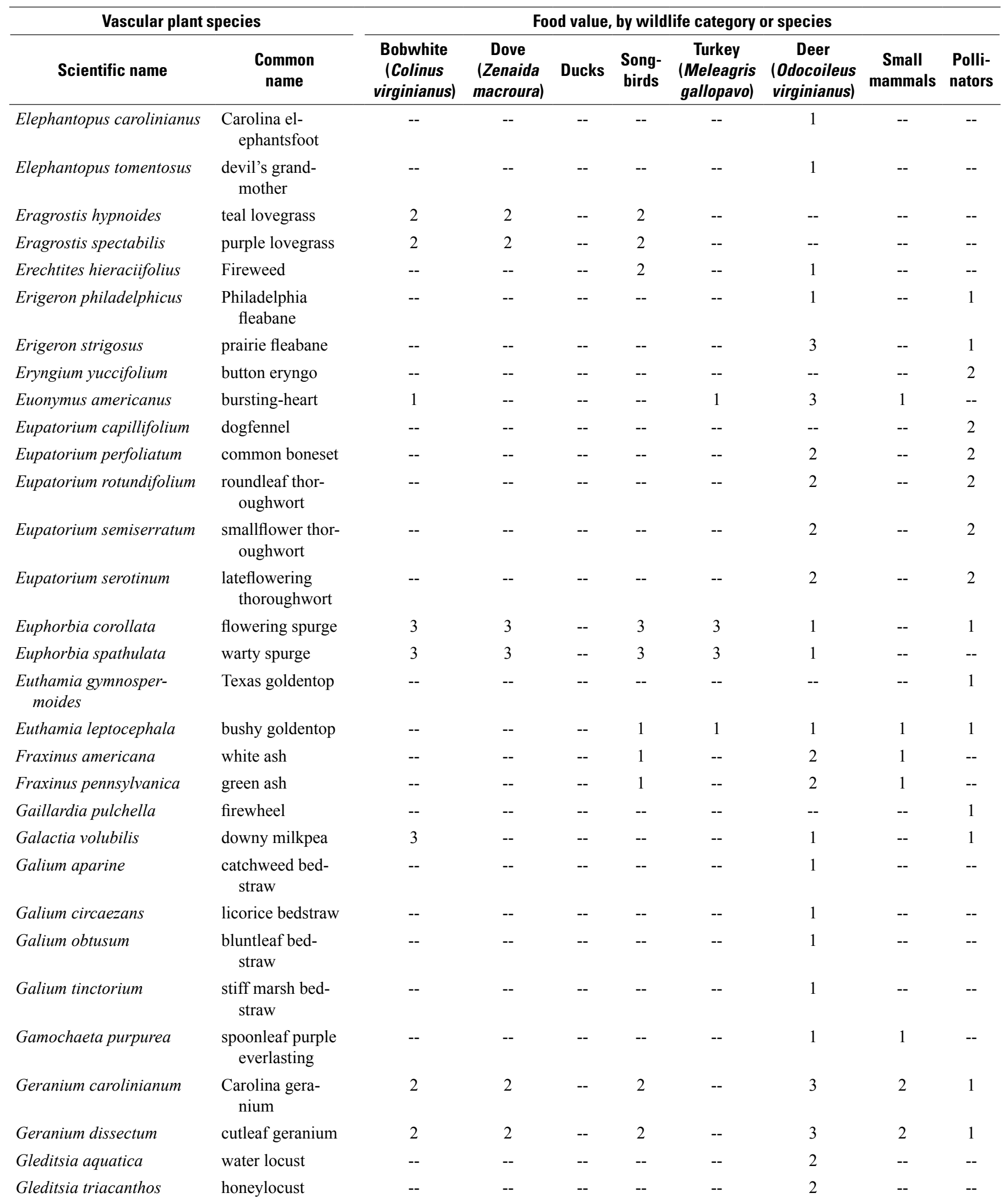


Table 3. List of vascular plant species found at Caddo Lake National Wildlife Refuge, Texas, March 2011-March 2012, with food value for wildlife.-Continued

[1, low use; 2 , medium use; 3 , high use. --, no data]

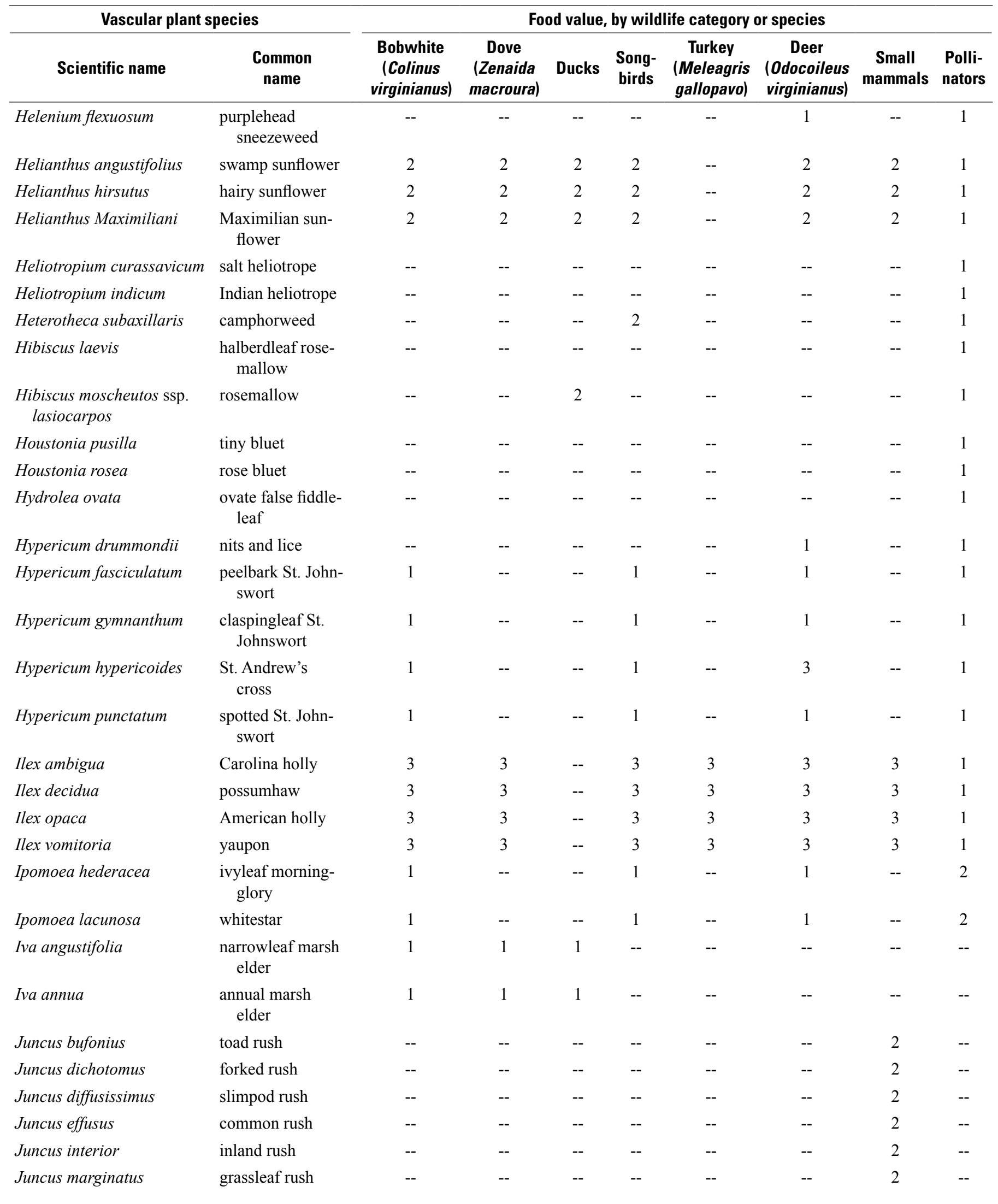


Table 3. List of vascular plant species found at Caddo Lake National Wildlife Refuge, Texas, March 2011-March 2012, with food value for wildlife.-Continued

[1, low use; 2 , medium use; 3 , high use. --, no data]

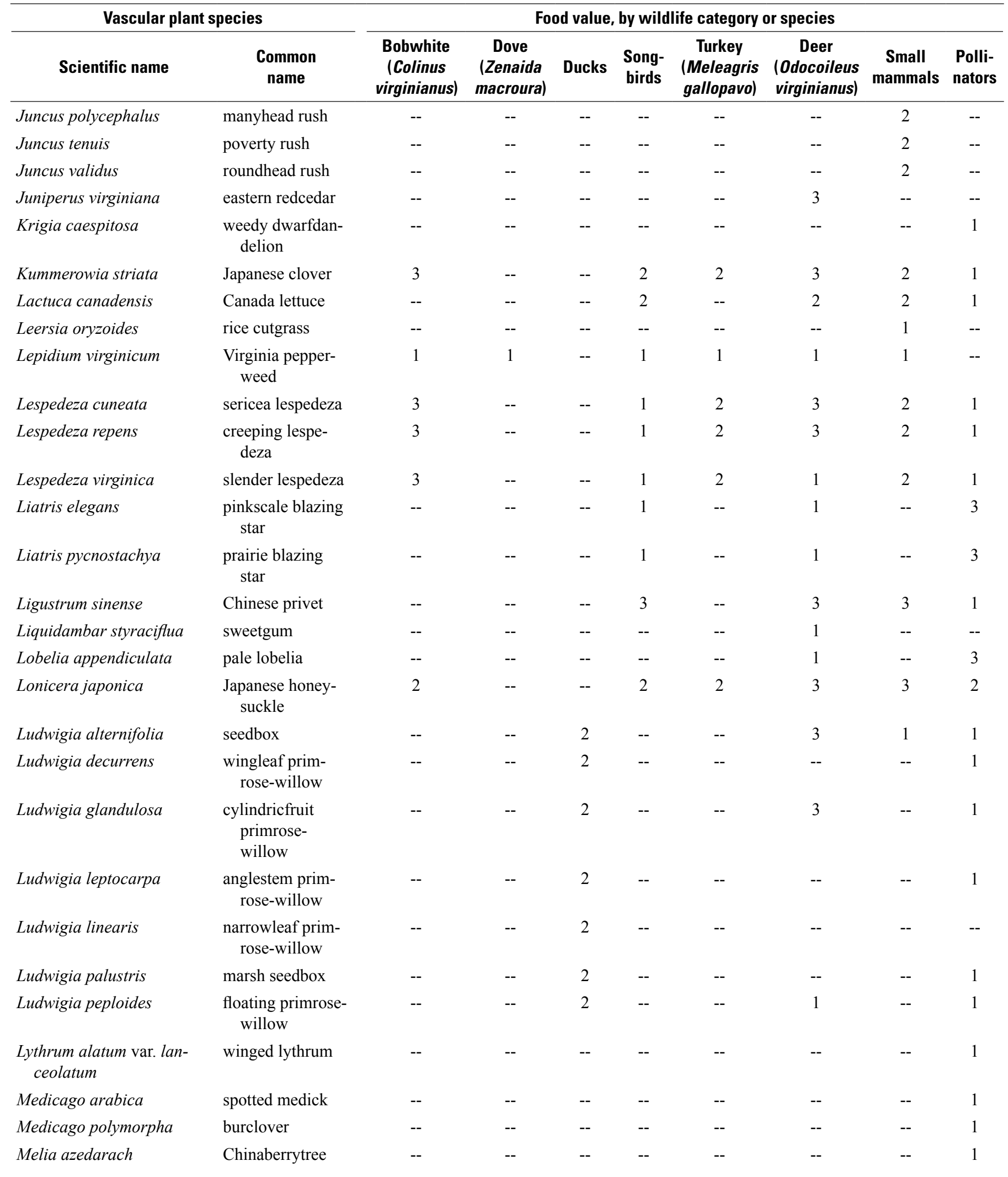


Table 3. List of vascular plant species found at Caddo Lake National Wildlife Refuge, Texas, March 2011-March 2012, with food value for wildlife.-Continued

[1, low use; 2 , medium use; 3 , high use. --, no data]

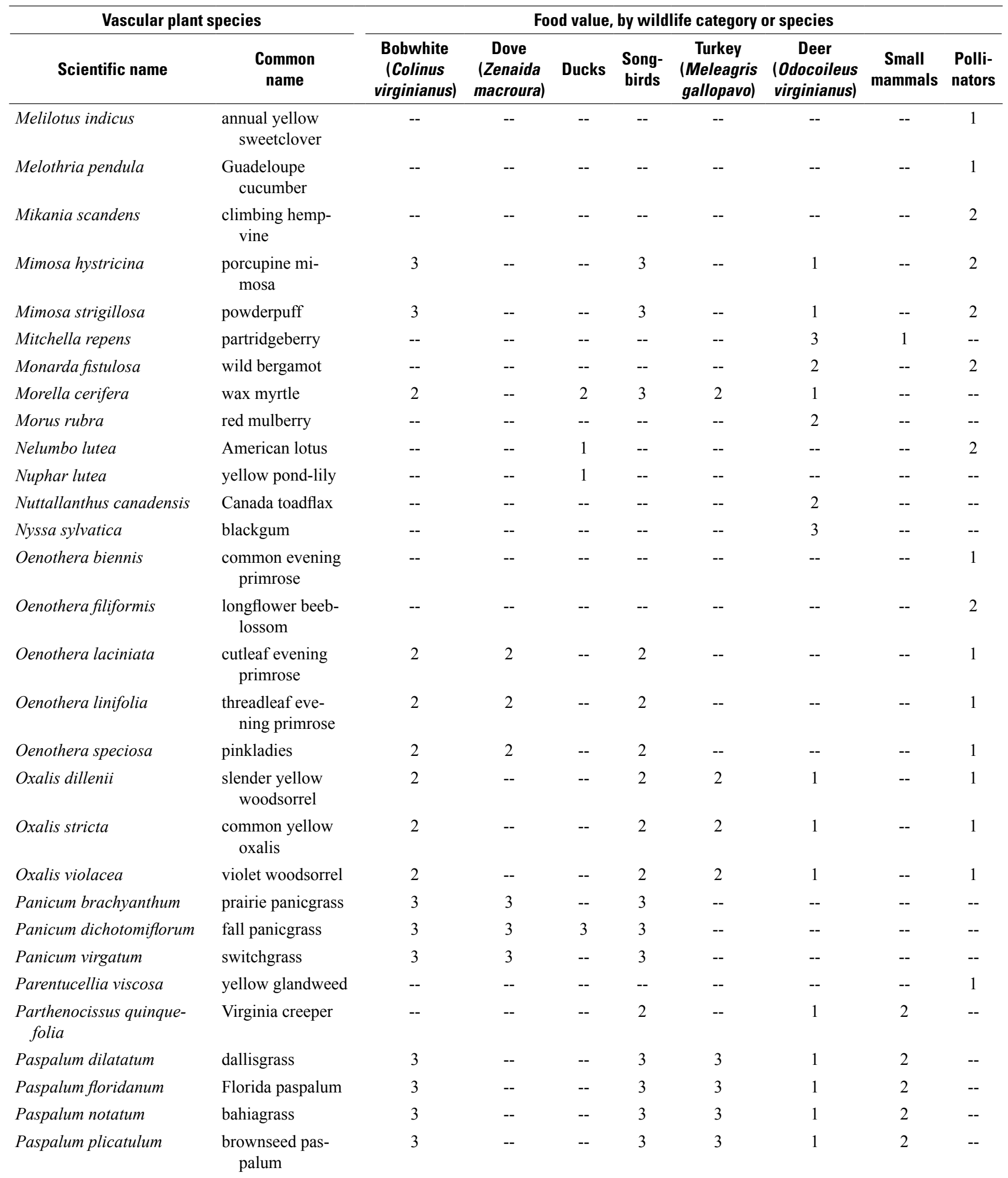


Table 3. List of vascular plant species found at Caddo Lake National Wildlife Refuge, Texas, March 2011-March 2012, with food value for wildlife.-Continued

[1, low use; 2 , medium use; 3 , high use. --, no data]

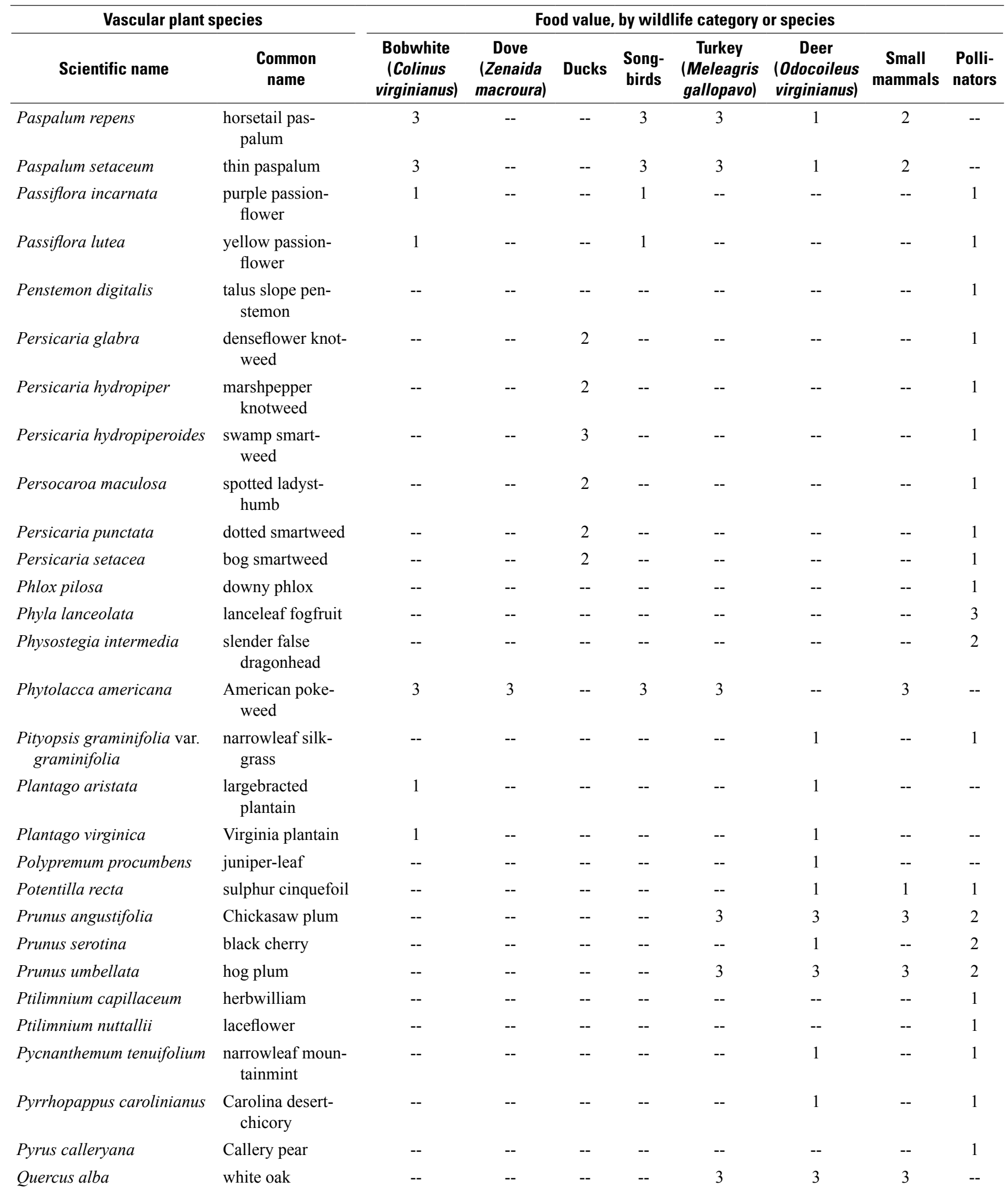


Table 3. List of vascular plant species found at Caddo Lake National Wildlife Refuge, Texas, March 2011-March 2012, with food value for wildlife.-Continued

[1, low use; 2 , medium use; 3 , high use. --, no data]

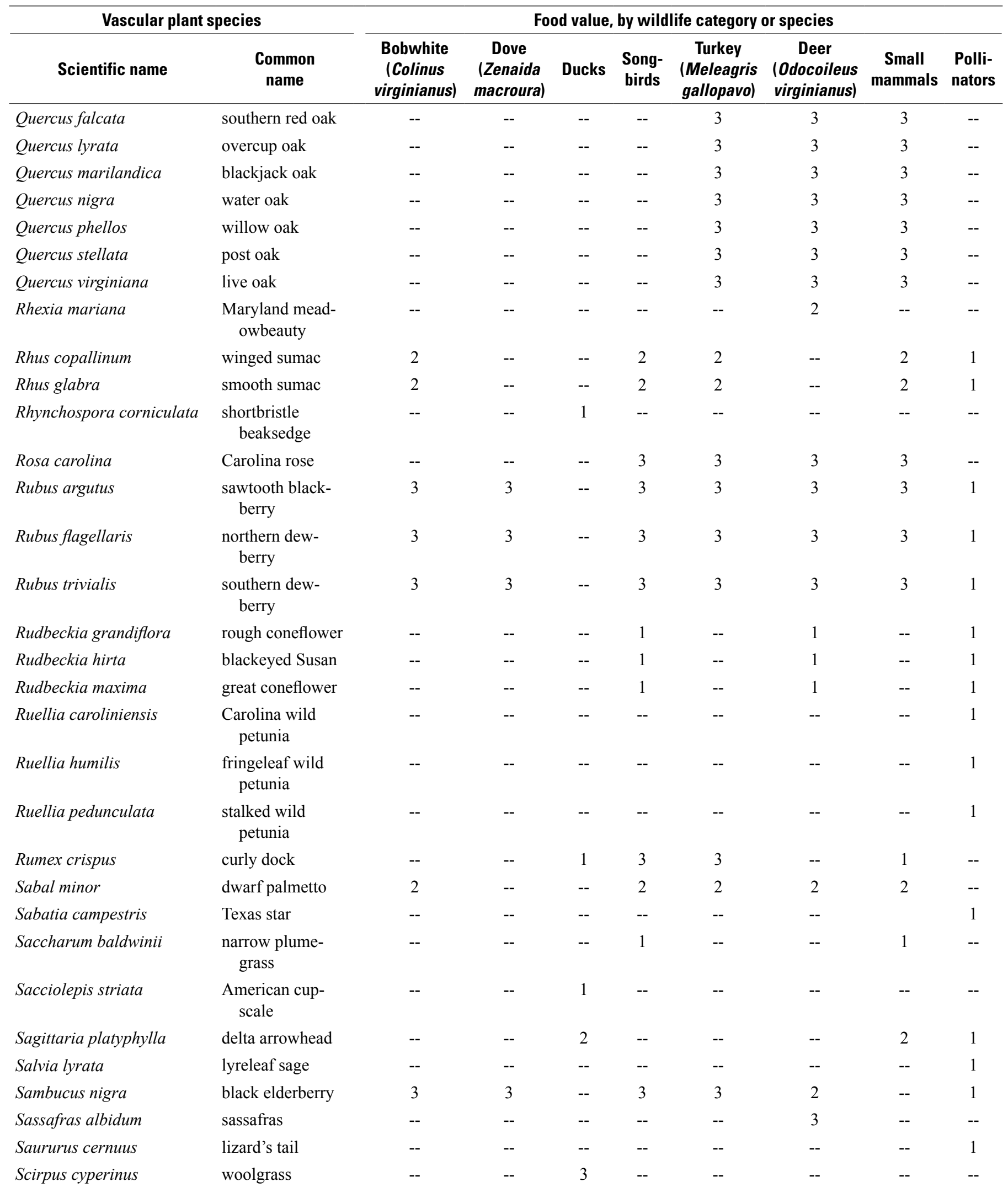


Table 3. List of vascular plant species found at Caddo Lake National Wildlife Refuge, Texas, March 2011-March 2012, with food value for wildlife.-Continued

[1, low use; 2 , medium use; 3 , high use. --, no data]

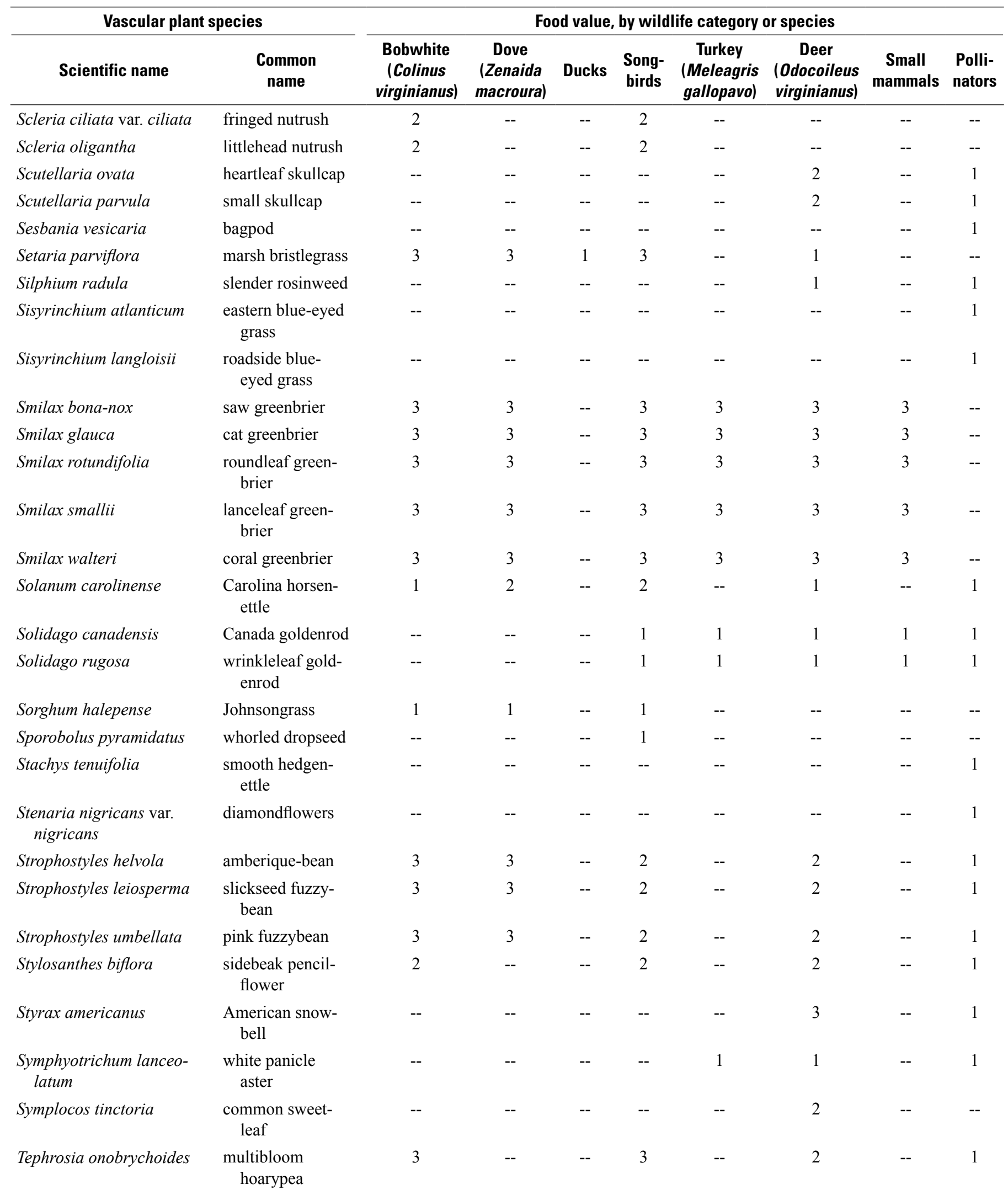


Table 3. List of vascular plant species found at Caddo Lake National Wildlife Refuge, Texas, March 2011-March 2012, with food value for wildlife.-Continued

[1, low use; 2 , medium use; 3 , high use. --, no data]

\begin{tabular}{|c|c|c|c|c|c|c|c|c|c|}
\hline \multicolumn{2}{|c|}{ Vascular plant species } & \multicolumn{8}{|c|}{ Food value, by wildlife category or species } \\
\hline Scientific name & $\begin{array}{l}\text { Common } \\
\text { name }\end{array}$ & $\begin{array}{l}\text { Bobwhite } \\
\text { (Colinus } \\
\text { virginianus) }\end{array}$ & $\begin{array}{c}\text { Dove } \\
\text { (Zenaida } \\
\text { macroura) }\end{array}$ & Ducks & $\begin{array}{l}\text { Song- } \\
\text { birds }\end{array}$ & $\begin{array}{c}\text { Turkey } \\
\text { (Meleagris } \\
\text { gallopavo) }\end{array}$ & $\begin{array}{c}\text { Deer } \\
\text { (Odocoileus } \\
\text { virginianus) }\end{array}$ & $\begin{array}{c}\text { Small } \\
\text { mammals }\end{array}$ & $\begin{array}{l}\text { Polli- } \\
\text { nators }\end{array}$ \\
\hline Teucrium canadense & $\begin{array}{l}\text { Canada german- } \\
\text { der }\end{array}$ & -- & -- & -- & -- & -- & -- & -- & 1 \\
\hline Toxicodendron radicans & eastern poison ivy & -- & -- & -- & 3 & -- & 3 & -- & -- \\
\hline Trachelospermum difforme & climbing dogbane & -- & -- & -- & -- & -- & -- & -- & -- \\
\hline Tradescantia hirsutiflora & $\begin{array}{l}\text { hairyflower spi- } \\
\text { derwort }\end{array}$ & -- & -- & -- & 1 & -- & 1 & -- & -- \\
\hline Tradescantia ohiensis & bluejacket & -- & -- & -- & 1 & -- & 1 & -- & -- \\
\hline Triadica sebifera & Chinese tallow & -- & -- & -- & 1 & -- & -- & 1 & -- \\
\hline Tridens strictus & longspike tridens & 1 & -- & -- & -- & 2 & 1 & -- & -- \\
\hline Trifolium campestre & field clover & -- & -- & -- & -- & -- & -- & -- & 1 \\
\hline Trifolium dubium & suckling clover & -- & -- & -- & -- & -- & -- & -- & 1 \\
\hline Trifolium incarnatum & crimson clover & -- & -- & -- & -- & -- & -- & -- & 1 \\
\hline Trifolium pratense & red clover & -- & -- & -- & -- & -- & -- & -- & 1 \\
\hline Trifolium repens & white clover & -- & -- & -- & -- & -- & -- & -- & 1 \\
\hline Typha latifolia & broadleaf cattail & -- & -- & -- & -- & -- & -- & 1 & -- \\
\hline Ulmus alata & winged elm & -- & -- & -- & -- & -- & 2 & -- & -- \\
\hline Vaccinium arboreum & farkleberry & 3 & -- & -- & 3 & 3 & 1 & -- & 1 \\
\hline Verbena brasiliensis & Brazilian vervain & -- & -- & -- & 1 & -- & 2 & -- & 3 \\
\hline Verbena halei & Texas vervain & -- & -- & -- & 1 & -- & 2 & -- & 3 \\
\hline Verbena urticifolia & white vervain & -- & -- & -- & 1 & -- & 2 & -- & 3 \\
\hline Verbesina virginica & white crownbeard & -- & -- & -- & -- & -- & -- & -- & 1 \\
\hline Vernonia texana & Texas ironweed & -- & -- & -- & -- & -- & -- & -- & 1 \\
\hline Vicia minutiflora & $\begin{array}{l}\text { pygmyflower } \\
\text { vetch }\end{array}$ & 1 & 1 & -- & 1 & 1 & -- & -- & -- \\
\hline Vicia sativa & garden vetch & 1 & 1 & -- & 1 & 1 & -- & -- & -- \\
\hline Vicia villosa & winter vetch & 1 & 1 & -- & 1 & 1 & -- & -- & -- \\
\hline Viola bicolor & field pansy & 2 & -- & -- & 2 & 2 & 2 & -- & 1 \\
\hline Viola sororia & $\begin{array}{l}\text { common blue } \\
\text { violet }\end{array}$ & 2 & -- & -- & 2 & 2 & 2 & -- & 1 \\
\hline Vitis aestivalis & summer grape & -- & -- & -- & 3 & 3 & 2 & 3 & -- \\
\hline Vitis cinerea & graybark grape & -- & -- & -- & 3 & 3 & 2 & 3 & -- \\
\hline Vitis riparia & riverbank grape & -- & -- & -- & 3 & 3 & 2 & 3 & -- \\
\hline Vitis rotundifolia & muscadine & -- & -- & -- & 3 & 3 & 3 & 3 & -- \\
\hline Vitis vulpina & frost grape & -- & -- & -- & 3 & 3 & 2 & 3 & -- \\
\hline Wisteria frutescens & American wisteria & -- & -- & -- & -- & -- & 2 & -- & 2 \\
\hline Yucca louisianensis & Gulf Coast yucca & -- & -- & -- & -- & -- & -- & -- & 1 \\
\hline
\end{tabular}


Publishing support provided by Lafayette Publishing Service Center 


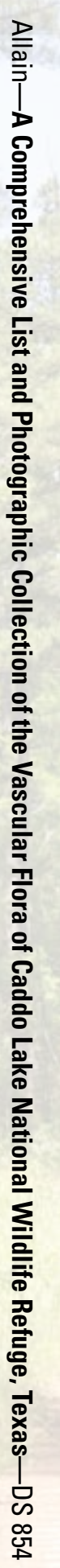

